\title{
Temas de Legislación Procesal
}

Demianda: Comparecencia ante el Juez y Competencia en el Código de Procedimientos Civiles.

Por ol Dr. ERNESTO PERLA VELACCHAGA. Catedrático Titular de Derecho Civil y de Derecho Procesal Civil (P.U.C.)

\section{I-DEMANDA}

Esta primera fase del Juicio, supone el estudio de varias cuestiones de las que vamos a presentar en dos distintos capítulos, quienes pueden comparecer ante el juez y ante quienes debe comparecerse o sea la relativa a la competencia.

\section{CAPITULO I}

\section{COMPARECENCIA ANTE EL JUEZ}

Las personas que ejercen por sí sus derechos civiles pueden litigar personalmente o por medio de apoderados; las que están incapacitadas para ejercer sus derechos civiles comparecen por medio de sus representantes (arts. $1^{\circ}$ y $2^{\circ}$ ). - Las reglas son en general para comparecer ya sea como actor o demandado.

Debe considerarse la comparecencia de los capaces y de los incapaces,

\section{COMPARECENCIA dE LAS PERSONAS CAPACES}

La comparecencia de las personas capaces puede revestir dos formas: A) Comparecencia personal; y B) Comparecencia por medio de otra persona.

\section{A) COMPARECENCIA PERSONAL.}

1) hay dos clases de capacidad: de goce $y$ de ejercicio. La primera es la aptitud para ser titular de un derecho; la segunda es la que permite a las personas ejercitar por sí mismas los derechos de las que son titulares. Todas las personas por el simple hecho de nacer con vida tienen capacidad de goce o de derecho; la capacidad de ejercicio solo la tienen estas mismas personas, mediante ciertas condiciones de idoneidad que la ley fija en resguardo generalmente de la misma persona. Para comparecer ante el juez se requiere la capacidad de ejercicio, que siempre supone la de goce. 
2) Son personas capaces de ejexcer por sí sus derechos civiles y por lo mismo pueden comparecer ante el Juez, los que han cumplido 21 años (1).. Excepcionalmente gozan del ejercicio de sus derechos civiles aquellas personas a quienes se les ha otorgado anticipadamente la mayoría de edad, cesando así su incapacidad y son aquellas mayores de 18 años, que han sido emancipadas, han contraído matrimonio u obtenido título oficial que les autorice para ejercer una profesión o industria (2), siendo necesario en el caso de matrimonio que sea mayor de 18 años y que se haya casado previo el respectivo consentimiento (art. $100 \mathrm{C}$. C.). Por el último el C. sustantivo otorga expresa y específicamente en algunos casos la facultad de comparecer ante el Juez a determinadas personas: a) a la madre menor de edad que intento una acción a nombre del hijo, durante la minoría de éste (3).-b) al menor para acciones que se refieran al ejercicio de la industria que ejerce con la debida autorización o relativas al trabajo que ejerce con el consentimiento del representante (4).-c) al menor que debe contradecir la negativa del Consejo de Familia para contraer matrimonio (5).-d) al mayor de 16 años para impugnar la cuenta presentada por su tutor (5).-e) al mayor de 14 años para reclamar por los actos de su tutor (6).

\section{B) COMPARECENCIA POR MEDIO DE OTRA PERSONA.}

Nótese que se trata de una facultad de las personas capaces para poder litigar o no por medio de otra pero hay casos en que por excepción o por naturaleza de la persona (persona jurídica) se le impone esta forma de litigar.

Consiste en la designación que hace un litigante para que otra persona ejercite su representación en juicio. Se trata de una forma del contrato de mandato civil por lo cual una persona llamada mandante, encarga a otra que se denomina mandatario o apoderado que ejercite por ella las facultades y asuma las obligaciones que las leyes procesales establecen. Se rige pues por las reglas generales del contrato de mandato.

Como esta representación puede referirse tanto $\alpha$ las personas físicas - naturales, como a las personas jurídicas, estudiaremos sucesivamente la representación de unas y otras, haciendo presente que a los representantes de los primeros se llama en nuestro Código de Procedimientos Civiles, apoderados; y de las segundas, mandatarios judiciales.

El documento en que consta la representación se llama el poder.

a) los apoderados.

Son así los representantes de las personas físicas capaces.-Aunqua la regla general es que el nombramiento de tales apoderados es facultativa, por excepción resulta obligatoria, en ciertos casos.

(1) Art. 89 del C. C.

(2) Art. 11 del C. C.

(3) Art, 376 C. C.

(4) Arts. 514 y 518 C. C.

(5) Ant. 99 C. C.

(6) Art. 532 C. C. 
1.-Nombranilento voluntario de apoderado.-Está justificado que una persona capaz litigue por medio de apoderado sin nịguna restricción y sin que pueda negársele tal forma de litigar, por causa de ausencia del lugar donde se tramita el juicio, carencia de tiempo o de ánimo para atenderlo, y tantas otras. No es necesario que exista causa alguna, pues basta la voluntad de la persona para que emplee ésta forma de litigar, sin que proceda restricción alguna que le impida hacerlo.

Esto sin perjuicio de obligarla a su personal comparencia en diligencias de carácter personal. Se puede exigir la comparecencia personal al juzgado del litigante que litiga por medio de apoderado cuando se trata de actuaciones que para que llenen sus objetivos, por tratarse de hechos personales deben pronunciarse las mismas personas que los practicaron; así para la confesión, el reconocimiento de documentos y el juramento decisorio puede exigir una parte que la otra, acuda personalmente aunque tenga apoderado constituído con facultad de practicar estas diligencias.

Por otra parte el mandante tiene la facultad irrestricta de salir a juicio on cualquier momento, revocando o no el poder que tenga constituído, o do sustituírlo en las circunstancias y persona que más le conviniere.

Acá se presenta el problema de saber si un litigante puede obligar al otro a que una de estas diligencias personales se entienda con el apoderado que tiene poder suficiente para practicarlas.

Sería el caso de solicitar la confesión de una persona que viviendo fuera del lugar del juicio tiene apoderado con facultad de prestar confesión. Quien la solicita pide que se entienda con el apoderado para librarse de la actuación por comisión. lejos del lugar donde se encuentra y fuera de su control o con dificultades para ejercitar debido control.

El apoderado para cualquier diligencia de carácter personal puede exigir que se notifique a su propio mandante para que él decida si debe o no practicarla. En tal caso la parte a quien se solicita la prueba puede ad. mítir que se actúe con su apoderado debidamente autorizado. No puedo imponer una parte que se actúen esta clase de diligencias con el apoderado aunque esté facultado para hacerlo, si el litigante representado no lo dispone así. Por ésto es que las diligencias personales siempre deben notificarse a las propias personas y no a sus apoderados; las partes decidirán con quien pueden entenderse.

En resumen: el representado y sólo él puede decidir que talos diligencias personales se entiendan con su apoderado; el contrario, puede aceptar esta decisión, o exigir la intervención personal del mandante.

Hemos dicho que la representación de las personas físicas capacer puede ser voluntaria, y excepcionalmente obligatoria.

2.-Qulenes son hábiles pora ser apoderados.-Arts. $5^{\circ}, 6^{\circ}$ y $7^{\circ}$. Ia regla general es que pueden ser apoderados las personas que gozan del ejercicio de sus derechos civiles. Debe notarse que hay personas quo pueden comparecer ante el Juez y que sin embargo no gozan de sus derechos civiles; éstas no pueden ser apoderados, tales los casos de la madre menor de edad, de los menores de 14 años, etc. Se requiere pues la cqpacidad plena ya sea por haber alcanzado los 21 años de edad o por concesión cnticipada de la mayoría o por simple concesión legal. 
La mujer casada puede ejercer el poder de su marido o de un extraño con autorización de aquel (art. $6^{\circ}$ ). - $\bar{A}$ pesar de que el C.C. art. 372-, permite a la mujer comparecer en juicio, contra autorizadas opiniones, ésto no significa que pueda ejercer la representación de cualquier persona sin autorización del marido, pues la razón de la exigencia está no sólo en la limitada capacidad de la mujer casada según el C. C. anterior, pues en este caso si habría desaparecido tócitamente con el C. C. de 1936, sino también en que la representación de la mujer casada puede comprometer los bienes comunes de la sociedad conyugal, de los que el marido continúa siendo el administrador, dada las obligaciones de abonar eventualmente costas y también de reparar los perjuicios que puede acarrear el ejercicio del poder.

Conforme al art. $7^{\circ}$ están prohibidos de ser apoderados en primer lugar el ciego, por razón de que este defecto no le permitiría la debida seguridad en el ejercicio del poder, dado el carácter y la forma de procedimiento.

En segundo lugar los sordo-mudos no pueden ser apoderados. Podría entenderse que se trata sólo de los que no saben expresarse en forma indubitable, pues únicamente ellos son incapaces absolutos según el art. $9^{\circ}$ del C.C. - Creo que no, sino que como en el caso del ciego, la prohibición radica on su defecto físico y no en su capacidad.

En tercer lugar la restricción para que el fraile no sea apoderado a no ser de su convento, se fundaba en que ellos están sujetos especialmente $\alpha$ votos de sujeción y obediencia, que los constituía según la antigua legislación en verdaderos muertos civiles. Pero hoy está derogado este precepto desde que los votos religiosos no tienen ninguna trascendencia en el Derecho Civil.

3.-Extenslón del poder.-arts. $9^{\circ}$ y $10^{\circ}$-Por su extensión el poder puede ser general y especial. Apesar de su denominación el primero es más restringido que el segundo. Su denominación obedece a que el poder general permite la representación en todos los actos comunes u ordinarioa mientras que el poder especial se requiere para actos procesales en particular, por eso el primero podría ser llamado poder común en contraposición al poder especial.

a) Poder general.-Se llama también el poder para pleitos._-"El poder para pleitos, es el que - art. 9'- confiere al apoderado todas las facultades que corresponden al poderdante, salvo aquellas para las que la ley exige poder especial. Toda limitación o reserva en contrario, se considera no puesta".

Este poder dá al apoderado todas las facultades que son necesarias para intervenir en la tramitación del juicio y nada más.

Esta suma de facultades no admite excepciones ni restricciones de ninguna clase. En el caso de que se otorgara un poder para pleitos negando al mandatario la facultad de absolver, por ejemplo un trómite procesal ordinario cualquiera, esta limitación se considerará no puesta, será obsolutamente ineficaz.

El fundamento de esta regla es obvio. No podría proseguir el juicio por defecto de poder, ni tendría justificación que hubiera un represen- 
tante para todo menos para absolver simples traslados, o para que se entienda con él el ofrecimiento de prueba u otro trómite necescrio, previsible y común en los juicios. En contraposición, el poder especial otorga facultades para ejercitar actos que importan decisiones más graves $Y$ generalmente actos de disposición.

b) Poder especial.-Es aquel que confiere al apoderado las facultades del art. $10^{\circ}$ que establece que: "se requiere poder especial para deeistirse de la demanda, convenir e nella, prestar confesión o juramento de. cisorio, deferir al del contrario, transigir el pleito, someterlo al arbitraje, pedir suspensión de pagos o presentarse en concurso o quiebra, emancipor, adoptar o prestar consentimiento para la adopción, sustituir el poder, y para los demás actos que exprese la ley".

El art. $10^{\circ}$ del C. de P. C. contiene una enumeración taxativa, de tal manera que sólo para estos actos se requiere poder especial.

Sin embargo, debe tenerse en consideración que el art. 415 del C. de P. C. dice: -"El reconocimiento puede practicarse por apoderado con poder especial, si el colitigante lo consiente. En el reconocimiento por apoderado, se procederá como lo dispone este Código cuando se trate del obligado". Este art. 415 señala un caso de poder especial que no está comprendido en el artículo $10^{\circ}$ y sobre el cual volveremos en su oportunidad. El art. 310 del C.P.C., impone también la obligación de poder especial para contestar demandas nuevas.

Estas facultades por importar actos de disposición o por lo menos de trascendencia, que sobrepasan las actuaciones simplemente procesales, deben ser expresamente concedidas por el poderdante.

Pueden ser concedidas todas o solo alguna o algunas de las facultades enumeradas en el art. $10^{\circ}$ del C. de P. C.. pero no puede jamás suponerse que el otorgamiento de una facultad de mayor trascendencia permite practicar un acto de menor importancia, así no debe deducirse que porque un apoderado tiene poder para convenir en la demanda, puede también transigir el juicio. Las facultades deben ser expresamente concedidas.

Además se requiere en los casos de los arts. 310 y 415 del C. de P. C.; otros casos están señalados en el C. C. (arts. 19, 152, 630, 1277, 1633, 1742 y 1745).

4.-Origen de la representación.-Por su origen el poder es legal, judicial y convencional.

a)-Legal.-Sería el caso de los representantes de las personas jurídicas de derecho privado interno a las que se refiere el ant. $3^{\circ}$ del Código de Procedimientos Civiles que dice: "Los gerentes o administradores de las sociedades civiles 0 comerciales, y los jefes o presidentes de las corporaciones o entidades con personalidad jurídica, de carácter privado, son sus mandatarios judiciales", desde que los gerentes, administradores, etc., ejercen por ministerio de la ley la representación de estas entidades aunque la extensión de sus facultades puede variar dentro de ciertos límites. Pero estos representantes, están en nuestra legislación considerados bajo 
el nombre de mandatarios judiciales $y$ de ellos nos ocuparemos más adelante.

b).-Judicial.-Es aquel cpoderado que es designado por el Juez. Estos casos constituyen una excepción al principio general de que las personas capaces pueden o no, según su voluntad, litigar por medio de apoderado. Pero en estos casos se impone la designación de apoderado, no por supuesto por falta de capacidad procesal, sino por razones de economía procesal, por deficiencias físicas en los litigantes que les dificultan la atención del juicio y por ausencia del litigante. Estudiaremos estos casos al referirnos a la designación involuntaria de apoderado.

c).-Convencional-Es el otorgado conforme a las reglas del contrato de mandato.

5.-Deslgnación obligatoria de apoderado.-Los casos en que procede la designación judicial, son los siguientes:

1.-Por peligro de ausencia:- arts. 119-120.- Según el art. 119: "el que tema que la persona con quien se propone litigar o que le "es responsable se ausente del lugar, puede pedir que señale do"micilio o constituya apoderado". "A esta solicitud se acompañará "un depósito de diez libras, que se devolverá al depositante si in"terpone su demanda dentro de tres días, o se entregará al venci"miento de este plazo a la parte intimada, en caso contrario".

Conforme al art. 120.--'Igual petición puede formularse al tiempo "de interponer la demanda o después, mientras el demandado no ha "designado domicilio; pero no será entonces exigible la constitu"ción del depósito".

Este es un procedimiento que ha venido a sustituir dentro del Código de Procedimientos Civiles a la institución del arraigo del antiguo C. de E. Conforme al arraigo, se prohibía que una persona con la cual se iba a litigar se ausentara del lugar de su domicilio. Conspiraba pues contra la libertad personal y de tránsito que consagra nuestra Constitución.

Conforme a este nuevo procedimiento ya no se puede impedir que la persona con quien se va a litigar quede sin salir del lugar, sino simplemente se le obliga a que señale un domicilio para que allí se le tenga siempre presente o que nombre un apoderado con el cual se entienda el juicio.

El requisito para que proceda antes de la interposición de la demanda es doble: el peligro de ausencia y que se acompañe a la solicitud un depósito de S/o. 100.00 en garantía de que se va a interponer la acción En el caso de que se cumpla con interponerla dentro del plazo de tres días, el depósito se devuelve al solicitante $y$ en caso contrario, corresponde a la persona intimada para resarcirse de los perjuicios que se le hayan podido ocasionar con el procedimiento.

Debe notarse que decretada la solicitud, se pueden presentar tres casos: $\alpha$ ) que el intimado cumpla con designar domicilio. Se cumple con 
el mandato judicial de cualquiera de los dos modos: nombrando apoderado - designando domicilio. En este último, la designación debe hacerse conforme a ley, esto es, dentro de los límites urbanos de la sede del Juzgado y allí se le harớn todas las notificaciones como si estuviese presente aunque en realidad no lo esté, hasta que cambie de domicilio. b) que el intimado opte por nombrar apoderado. En este caso, con él se entiende todo el juicio hasta que se le sustituya o el demandado salga personalmente al juicio, inclusive con la persona nombrada apoderado se entiende la notificación de la demanda o emplazamiento, a pesar de lo establecido por el art. 315 del C. de P. C., pues este apoderado ha sido nombrado precisamente con ese objeto. - c) el intimado no hace designación de domicilio ni nombra apoderado. En este caso se sigue el juicio en su rebeldía. Consiste esta en una sanción de carácter procesal que coloca al rebelde en determinada situación dentro del proceso, como se estudia más adelante. Debe notarse que la sanción no consiste en la designación de apoderado por el juez, sino en la declaración de rebeldía del intimado. Entonces al interponerse la demanda se acusa rebeldía $y$ si es necesario se notificará ésta por el periódico.

Hay aún otra posibilidad que la ley no contempla y es que el intimado no cumpla con el mandato del Juzgado pero tampoco se ausente. En este caso también debe fijar domicilio para no quedar en la situación de rebelde.

2.-Por ausencia del lugar del juicio.-art. 12, primera parte. Por estar el litigante fuera del lugar donde se sigue el juicio.-según el art. 12, primera parte:- "Puede exigirse que el litigante nombre apoderado para el pleito, si se encuentra en lugar distinto de aquel en que se sigue".

Debe evitarse que haya que omplear los exhortos para cada notitificación lo que recargaría no sólo los gastos sino también la duración del juicio por las repetidas concesiones del término de la distancia. Por esto es que se permite ésta forma de evitar tales perjuicios, solicitando el nombramiento de apoderado que resida, por supuesto, en el lugar del juicio.

3.-Por defecto físico.- Conforme al art. 12, segunda parte: -"El sordomudo y el ciego deben siempre litigar por apoderado. No cumpliéndose en éstos casos con nombrar apoderado, se seguirá el juicio en rebeldia".

Indudablemente que éste precepto no se justifica sino por cuanto las personas que padecen de éstos defectos no se encuentran en condiciones de atender al juicio debidamente. No se trata de personas incapaces.

El sordomudo a que se refiere este artículo no es el que conform. al Código Civil es incapaz, sino al sordomudo que puede expresarse en forma indubitable sirviéndose de los diferentes medios ideados para ello. En caso de incapacidad, su representante legal debe accionar por él. En el caso presente sólo es un apoderado, no un curador.

Planteadas asi las cosas puede discutirse la necesidad de que esta clase de sordomudos litiguen necesariamente por medio de apoderado, desde que en estos casos saben leer $Y$ escribir $Y$ siendo el procedimiento 
escrito no han de encontrar dificultad alguna, pudiendo las diligencias de confesión o reconocimiento, hacerse por escrito también o valerse de un intérprete como cuando se trata de personas que no dominan el idioma usual.

4.-Por razón del número de ligantes.-Ârts. 13 y 14 .-A Art. 13"Si son dos o más los demandantes o demanđađdos nombrarán apoderado común; pero se les autorizará para litigar por separado, si existe o aparece incompatibilidad de intereses entre ellos". - Art. 14 - $\mathrm{El}$ nombramiento de apoderado común se hará por acuerdo de todos o de la mayoría do los interesados.

"En caso de omisión de éstos o si no hubiese mayoría, se hará el nombramiento por el juez".

Entonces, si son dos o más los demandantes o demandados nombrarán un apoderado común. La razón es evitar innecesariamente los trámites y gastos que suponen las actuaciones para varias personas que en rigor constituyen una sola parte, $Y$ conforman la figura procesal del litis consorcio, varias personas en la situación de demandantes o demandados, que representan una misma pretensión o una misma excepción. El litis consorcio activo (varios demandantes), el pasivo (varios demandados) y el mixto (vorios demandantes y demandados), pueden llevar conforme a estos artículos a la obligación del nombramiento de apoderado común.

La parte que se enfrenta a éstas varias personas puede solicitar quo todos ellas designen apoderado común.

El procedimiento es el siguiente:- el juez a solicitud de parte interesada ordena que procedan a la designación de apoderado común. Estrictamente éste pedido no debe decidirse, sino después de contestada la demanda para poder saber si hay o no incompatibilidad de intereses entre aquellas personas a quienes se pide designar apoderado común.

Las personas intimadas para hacer tal designación pueden proceder de éstqs maneras: - $a$ ) oponerse al mandato del Juzgado; b) pedir autorización para litigar por separado; c) allanarse a dicho mandato.

a).-Puede oponerse al mandato del juzgado.

En el primer caso la oposición no puede fundamentorse sino en que no se reune el supuesto de hecho de la ley. Caso de que no exista un litis consorcio porque cada uno de los actores o demandados tengan derechos incompatibles entre ellos, así la demanda contra el propietario de un carrọ, el chauffeur y la Cía. de Seguros, por el pago de una indemnización por daños ocasionados por accidente de tránsito, si el propietario del vehículo sostuviera que la Compañía era la responsable del pago, y contra el dicho del chofer afirmara que no era su empleado, en este caso no hay litis consorcio y no sería aplicable la regla establecida para él.

Es por ésto que no debe atenderse el pedido de nombramiento de apoderado común sino después de fijadas las posiciones con la contestación a la demanda, si se trata de litis consorcio pasivo.

b).-Puede allanarse al nombramiento de apoderado común. Las facultades del apoderado común si es convencional tienen la 
extensión que le acuerden los interesados. Si es judicial tienen las del poder general para pleitos.

Designación convencional - art. 14. - Los interesados se ponen de acuerdo y designan un apoderado común. El poder se otorgará valiéndose de cualquiera de las formas permitidas y con la extensión que se convenga.

Designación judicial.-Art. 14.- En caso de que los interesados no cumplan con el mandato judicial que les ordena la designación de apaderado o no se reuna la mayoría, el juez hace la designación. El nombramiento puede recaer en alguno de los interesados, o en un tercero, siendo lo primero lo usual y corriente $\mathrm{y}$ entre aquellos, en el que tiene mayor interés en el pleito. El procedimiento para esta designación aunque no está cstablecido expresamente, se reduce al mandato, al apercibimiento y mediante el acuse de rebeldía por incumplimiento, el juez procede a la designación.

Entre los efectos de esa designación cualquiera que sea su forma, está que las partes no puedan apersonarse independientemente.

La revocación del poder al apoderado no surte efectos mientras no se nombre nuevo apoderado y ésto salga a juicio -art. 16-.

\section{e).-Pedir autorización para litigar por separado.}

Pueden solicitar autorización para litigar por separado si existe o aparece incompatibilidad de intereses entre ellos.

Quizós podría considerarse este caso comprendido en el primero de los anteriores, pero aunque es similar no es igual. En el caso anterior es una oposición al mandato $y$ en este es más bien una solicitud de licencia para ser desligado de la obligación de designar apoderado común. Casi siempre esto sucede con posterioridad al mandato que ordena el nombramiento de apoderado común y aún a la designación de éste. Puede pues admitirse que en cualquier momento que sobrevenga una incompatibilidad, la parte puede solicitar y obtener licencia para litigar por separado.

5.-Obligaciones $\mathrm{y}$ derechos del apoderado. Art. 1 1. - De conformidad con el Código sustantivo y en términos generales, el apoderado está obligado a continuar el juicio dentro de los límites de la representación que se le ha conferido.

Además, está obligado a pagar los gastos, costas y multas judiciales en que haya sido condenado el poderdante en el pleito. Este pago le dá derecho a repetir contra su mandante.

6. - Caro de renuncia del mandatario. - Art. 17 - segunda parte.El mandatario en principio está obligado a atender la representación conferida, pero puede sin embargo, separarse del pleito, haciendo notificar al mandante por decreto del juez para que lo subrogue o salga al juicio, y después de diez días, más el término de la distancia, desde la fecha de esa notificación. Si el interesado no sale a juicio por sí o por apoderado, el juicio continúa en rebeldía".

Cuando el mandatario hace uso de la facultad de separarse del 
juicio, mediante la previa notificación al mandante para que dentro del término de diez días nombre nuevo apoderado o salga al juicio, si el repre. sentado no cumple con éste mandato, vencido el término, el Juez no hace la designación, sino que ordena que se siga el juicio en rebeldía del mandante.

Así pues en este supuesto como en el examinado anteriormente, caso de peligro de ausencia, solo existe la orden del Juzgado para que se designe apoderado, excepción a la regla de designación voluntaria, pero no se produce designación judicial de apoderado.

7.-Formas de constituir el poder.-Art. $8^{\circ}-$ Por poder se entiende el instrumento en que consta el contrato de mandato.

Este instrumento debe ser presentado o por lo menos invocado siempre que una persona comparezca ante el juez a nombre de otra. Esta obligación la impone el art. 1640 del C.C. - Si el documento es público $y$ ha sido presentado ya en otro juicio, basta referirse a él pidiendo que se ordene al actuario poner en autos copia del poder, sin que mientras tanto se le tenga por acsptaảa su calidad de apoderado de una de las partes. Esta presentación tiene por objeto el que se pueda apreciar la suficiencia del poder.

Este instrumento se puede otorgar en cuatro formas diversas.

a) por escritura pública. El que se otorga por medio de un instrumento de esta clase y por lo tanto con las formalidades establecidas por la Ley del Notariado.

Este poder sirve para todc clase de juicios, aún para las acciones no entabladas y sin discusión puede ser general o especial, ésto es de cualquier extensión.- Debe ser inscrito en el Registro de Mandatos conforme al Art. 1066 del C. C., en el lugar donde vó a ejercerse, Art. 1067 del mismo Código.

b) por acta ante el juez de la causa.- Consiste en un acta que se otorga, conforme a la ley ante el juez que sustancia el pleito, y que es suscrita por éste, por el poderdante y el actuario.

En el caso que se otorgue ante las Cortes Superiores, el acta la suscribe el Presidente de la Sala, ante la cual se encuentra el pleito con intervención del Secretario respectivo.

Este poder no surte efecto sino para el juicio que se ha otorgado.

Esta clase de poder no requiere de su inscripción en el Registro de Mandatos, según se ha aclarado por el acuerdo de la Corte Suprema de 23 de Diciembre de 1937, que está perfectamente justificado desde que la finalidad de la inscripción, es que se conozca por los interesados, la vigencia y límites de la representación y tratándose de poder de esta clase, el único interesado es la persona o personas con quienes se sigue el litigio dentro del cual se otorgó desde que solo surte efectos dentro de esa causa $y$ el hecho de su vigencia $y$ demás tiene que aparecer de los mismos autos.

Esta clase de poder sirve igualmente para toda clase de litigios cualquiera que sea la cuantía y tramitación que le corresponda.

Respecto a la extensión que puede darse al poder por acta hay quienes sostienen que solo puede emplearse para otorgar poder general. Se fundan en el texto de la primera parte del art. $8^{\circ}$ que a la letra dice: 
"El poder general se presenta por escritura pública o por acta..." pareciendo que el poder especial sólo puede revestir la forma de la escritura pública.

Sin embargo, siendo evidente que la forma solo se exige para revestir el acto de la necesaria autenticidad y la intervención del juez y del actuario se equipara a este respecto con la del notario, se debe concluír que también el poder especial se puede otorgar por acta extendida ante el juez de la causa; además así lo reconoce la práctica.

c) poder fuera de Registro.- Constituye el poder que se otorga ante notario, con las mismas formalidades de las escrituras públicas pero sin minuta según el art. 75 de la L. del N.- Estos poderes no se transcriben al Registro del notario.

Este poder no sirve actualmente sino para las causas cuya cuantía no excede de $S / .10,000.00$. - Por lo tanto no procede apersonarse con poder de ésta clase en los juicios que se tramitan por la vía ordinaria. La segunda parte del art. $8^{\circ}$ del C. de P. C.. prescribía que sólo se admiten en causas cuya cuantía no exceda de S/. 500.00 o en las criminales por faltas.

La ley 13036 por su art. $9^{\circ}$ inc. b), ha modificado el art. $2^{\circ}$ de la ley 11362 derogatorio del art. 74 de la Ley de Notariado, estableciendo que "los Notarios pueden extender poderes fuera de Registro para las causas cuyo valor no exceda de diez mil soles y para las criminales por faltas", aumentando así la cuantía que conforme a la Ley anterior era sólo de dos mil soles.

d) poder por carta. - Es el que se otorga por documento privado $y$ con la única intervención de dos testigos. Esta clase de poder solo se admito ante los Juzgados de Paz y los Privativos de Trabajo.

8. -Terminación del cargo de apod:rado.-Arts. 17 y 18.- Pueden señalarse casos de terminación voluntaria o involuntaria.

Terminación voluntaria. Hay que distinguir cuando es por voluntad del mandante y del mandatario.

a) por voluntad del mandante termina el cargo de apoderado, por revoración. - El mandante puede en cualquier momento revocar el poder.

Puede verificarlo en forma expresa o tácitamente apersonándose el representado sin dejar a salyo la representación.

Tiene el efecto de no producir resultado mientras el litigante reprosentado no sale a juicio o sustituye al apoderado (art. 17 primera parte):- En los casos de revocación o renuncia del poder, o cargo que confiere la representación, no cesa ésta en el juicio pendiente, mientras la parte no sale a él o constituye nuevo personero".

Esto significa que debe seguir entendiéndose el procedimiento con el apoderado cuya representación se ha revocado mientras no se nombre nuevo apoderado o salga $\alpha$ juicio el representante.

b) por voluntad del apoderado, el cargo termina por renuncia. Art. 17, segunda parte. Conforme a las reglas generales del mandato, el apoderado no puede abandonar la representación y aunque la haga ésta actitud no surte efectos mientras no es reemplazado. 
Por eso se permite que el apoderado se pueda separar del juicio, haciendo notificar al mandante con decreto del juez para que lo subrogue - salga a juicio dentro del término de diez días, más el de la distancia, desde la fecha de esa notificación, bajo el apercibimiento de seguirse el juicio en su rebeldía.

Al cabo de este término se procede a declarar rebelde al intimado que no cumplió con hacer la designación de nuevo apoderado o salir personalmente al juicio.

Terminación involuniaria del cargo de apoderado.- Termina por la muerte 0 inhabilitación, ya sea del mandante o del apoderado, según el art. 1649 del Código Civil.- Art. 1649, ine. $3^{\circ}:-$ "El mandato se acaba por muerte, interdicción o quiebra del mandante o mandatario". En este caso por efecto de la terminación del mandato, sí se produce la suspensión del procedimiento, conforme al art. 18:- "En los casos de muerte o inhabilitación legal del mandatario se suspenderá al procedimiento mientras la parte sale al juicio o constituye nuevo personero.

"Si notificada judicialmente para hacerlo, no lo verifica y transcurre el término señalado en el art. 19 -diez días-, continuaráx el juicio en rebeldía".

$\mathrm{Si}$ se trata de muerte del mandante, el juicio tiene que continuar con sus herederos y a faitc de éstos, con el defensor de que trata el art. 1269 del Código de Procedimientos Civiles:- "Si no ha llegado el caso de nom. brarse administrador $y$ es preciso atender a la representación de la herencia, el juez nombrará un defensor a petición de cualquiera persona que tenga interés en que se provea a dicha representación.

Los términos judiciales no corren contra la sucesión en el tiempo que transcurre entre la petición y el nombramiento de defensor".

Así en el caso de muerte del mandatario el juicio se suspende pero el interesado puede hacer use de la facultad de que ya se ha trutado, ésto es solicitar que se notifique judicialmente a la parte para que salga a juicio o constituya nuevo personero y si no lo hace dentro del plazo do diez días continúa el juicio en su rebeldía.

En caso de muerte de uno de los que litigan con un apoderado común, la representación vaca por aplicación del art. 1649 del C. C.. si la designación ha sido convencional, pero nó en el caso de haberse hecho la designación judicialmente.

Representación de las personas jurídicas de derecho privado. Mandatarios fudiciales.

Aunque el C de P. C., no es muy preciso pues trata dentro del mismo título de los mandatarios judiciales y de los apoderados, creo que se puede entender por los primeros a los representantes de las personas jurídicas de derecho privado, y a los segundos como los representantes do las personas físicas naturales capaces.

las personas jurídicas necesitan valerse de personas tísicas para ejercer su capacidad de ejercicio.

Las personas jurídicas de derecho privado están representadas en 
juicio o pueden comparecer en juicio por medio de sus mandatarios judicíales; en cambio las personas jurídicas de derecho público interno lo hacen por medio de representantes legales.

El mandatario judicial no puede ser confundido con el apoderado y está, en la línea intermedia entre éste y el representante legal.

El mandatario judicial participa de los caracteres de ambos. -De los apoderados, porque son designados libremente $Y$ de los segundos porque ellos son obligatoriamente las personas que desempeñan ciertos cargos dentro de estas entidades; son los representantes de ellas necesariamente conforme al art. 3:- "Los gerentes o administradores de las sociedades civiles o comerciales, y los jefes o presidentes de las corporaciones o entidades con personería jurídica, de carácter privado, son sus mandatarios judiciales".

Pero la designación para éstos cargos es voluntaria y libremente hecha por los asociados.

Existen también diferencias en cuanto a la extensión de sus facultades.

La amplitud de la representación de los apoderados depende de la voluntad del mandante y tiene como mínimo la del poder general para pleitos (art. 99); en cambio las atribuciones mínimas del representante de personas jurídicas de derecho privado interno son más extensas, porque comprenden las del poder general para pleitos, más las de prestar confesión (art. 49) y reconocer documentos (art. 424, segunda parte).

Debe notarse que se hace una distinción entre las sociedades (civiles y comerciales o compañías) y las asociaciones, que designa el Código con el nombre de corporaciones. Todavía cabe una distinción de las compañías, entre compañías anónimas por una parte; y compañías colectivas - en comandita. Son personeros de las primeras los gerentes y de las segundas los administradores, pues no tienen gerente. De las asociaciones son sus mandatarios judiciales, sus jefes o presidentes.

Debe tenerse presente que éstas reglas son supletorias como la mayoría de las que se refieren a organización interna de las sociedades $y$ aún de las asociaciones en los respectivos Códigos sustantivos y así la representación la ejerce el gerente salvo el caso que en los Estatutos no t haya dispuesto otra representación.

Forma de la representación.- Puede constituírse únicamente por el simple nombramiento para el cargo, pero además se puede y se suele otorgar un poder, por la razón principal de que trecuentemente además de las facultades que la ley dá a éstos representantes, los socios o los aso. ciados, hacen uso del derecho de otorgarles otras facultades.

Extensión de la representación de los mandatarios judiciales de las: personas jurídicas de derecho privado.-El art. 49 establece que: "La amplitud de la representación de que trata el art. $3^{\circ}$, es la que establece el poder general para pleitos y comprende, además, la facultad de prestar confesión y las que expresamente se confieren".

Ásí los mandatarios judiciales tienen las facultades del poder general para pleitos, más la de prestar confesión. 
Esta última facultad corresponde al poder especial dentro de la representación individual pero en éste caso, por razón de la propia naturaleza de la persona, se le otorga al representante de la misma. La eficacia de la confesión que prestan queda sujeta a la regla del art. 368 del C. de P. C.

Estas facultades no pueden ser limitadas ni negadas, pues se trata de atribuciones legales de tal manera que toda restricción o reserva que se establezca se considera no puesta según la última parte del art. 4":- "No pueden hacerse valer en contrario las limitaciones o reservas que contengan los estatutos o actas de la sociedad, corporación o entidad jurídica".

Pero si la representación de éstos mandatarios judiciales en cuanto a su extensión tiene un mínimo (las facultades del poder para pleitos más prestar confesión y reconocer documentos), no tiene un máximun, pues las entidades pueden otorgarles además, todas las atribuciones $\mathrm{y}$ facultades que crean convenientes.

Fin de esta representación. - Art. 17.- Esta representación termina por causas voluntarias mediante la cesación en el cargo que confiere la representación y por la renuncia según el art. 17.

Esta cesarión por renuncia, por destitución, o por vencimiento del período, no surte efectos mientras no se provea nuevamente el cargo de tal manera que en éstos casos el juicio no se paraliza (art. 17).

También pueden terminar por causas involuntarias como muerte o inhabilitación del representado.

\section{Representanies legales}

Procurando obtener una definición de los representantes legales atendiendo únicamente al sentido de tales en nuestro C. de P. C., estimo que podrá decirse que por ellos se entiende a los que ejercen por ministerio de la ley la representación del Estado, de las personas jurídicas de derecho público interno, de la mujer casada y de los incapaces.

Ffectivamente examinando la materia de esta parte del Código. ésto es la contenida entre los arts. 19 a 28, se comprueba que todas ellas son reglas que proveen a la representación de las nombradas personas tanto jurídicas como naturales.

No se trata únicamente de la representación de las civilmente incapaces, desde que se considera entre los representantes legales a los personeros del Estado, que por supuesto, tanto dentro del derecho público como privado, constituye una entidad con personería jurídica.

Así, se podría salvar cualquier aparente contradicción o error en la clasificación admitiendo que la denominación de representante legal, corresponde a la persona que representa $\alpha$ aquellos que por su propia naturaleza (persona jurídica), por estar sujeta $\alpha$ un estatuto especial en el ejercicio de sus derechos civiles (mujer casada) o por carecer de capacidad (incapaces) no pueden litigar por sí mismos.

Se justifica que la ley dote de tales representantes a las personas juridicas de derecho público interno, Estado, Corporaciones oficiales, estable- 
cimientos públicos de instrucción y beneficencias y en general a las corpo. raciones oficiales o entidades del mismo carácter (art. 19);

El artículo pertinente es el que no deja ésta designación sometida a la voluntad como en el caso de las personas juridicas de derecho privado.

Art. 19:- "El Estado, los concejos municipales, juntas departamentales, establecimientos públicos de la instrucción y beneficencia y en general las corporaciones oficiales o entidades del mismo carácter, con personalidad juridica, son representadas en juicio por el funcionario designado por la ley".

La ley provee a su representación distinguiéndoles de las personas jurídicas de derecho privado, porque en estas últimas existe sólo un interés meramente privado, mientras que en aquellas hay un interés público; porque no existe en ellas una voluntad colectiva tal como existe y se manifiesta en las compañías anónimas, por ejemplo; $y$, porque no se considera conveniente que la representación sea ejercitada en forma que pueda variar en cada caso aunque no sea sino porque no hay estatutos que los intere. sados puedan conocer $y$ así la ley suple ésta situación determinando al personero de éstas entidades en razón del cargo que se ejercita dentro do ellas.

Los representantes legales se diferencion do los mandatarios judiciales en que éstos son designados libremente en cuanto al cargo que ejerce la representación, pues las reglas al respecto tienen la calidad de supletorias y en cuanto a la persona que se designe para esos cargos; tratándose de los representantes legales, el cargo que ejerce la representación es fijo y está determiando por la ley.

También se diferencian en cuanto a sus tacultades, pues mientras el máximum de la extensión de las facultades del mandatario depende de la voluntad de los mandantes; las facultades máximas y mínimas de los representantes legales están expresamente determinadas en la ley.

Sin embargo es evidente la diferencia que existe entre los representantes legales por razón de la persona a la que representan, por lo que estudiaremos esta materia distinguiendo a cada uno de éstos.

\section{Representantes legales de las personas juridicas de derecho público interno}

Estas personas tienen como representante legal al funcionario designado por la ley.

En cada caso la ley que crea $\alpha$ éstas personas jurídicas determinan quien ejerce su representación.

Al Estado, como persona de derecho público o privado, pues no se hace entre nosotros, distinción alguna, lo representan en juicio los Procuradores Generales de la República, que son los que comparecen ante el juez en representación del Estado. Conforme $\alpha$ la ley ésta puede ser ejercida fuera de lima por los abogados que se nombren para cada caso, particular. 
La ley 8489 de 30 de Setiembre de 1936, que creó las Procuradurias Generales de la República y su Reglamento, el D. S. de $1^{\circ}$ de Octubre de 1954, lo establecen así.

A las Municipalidades, las representan los Síndicos, ambos, según L.O. de M. - Art. 83, inciso $1^{\circ}$.

A las Universidades, Colegios de Segunda enseñanza, con personería jurídica, sus Rectores o Directores, conforme a la Ley Orgánica de Educación (Estatuto Universitario, Ley 6041, art. 49, Decreto Ley 7193, art. 4 ㅇ, etc.) Ant. 13 de la ley 13417.

Estatutos.

A los Colegios Abogados, el síndico, conforme al art. 23 de los

Cada vez que la ley crea una nueva persona jurídica de esta calidad, designa al funcionario que ejerce su representación. De tal manera que para decidir sobre éste punto puede ser necesario, buscar la ley de la materia, pues el C. de P. C., solo indica en general que ellas deben comparecer ante el juez, por medio del funcionario que la ley determina.

Extensión de sus facultades - art. 27 - Ia regla se reduce a que: 1) hay actos que el representante no puede realizar, pero ellos son más bien considerados en el campo del derecho sustantivo; 2) otros que debe realizar con ciertas formalidades como convenir en la demanda (art. 324) o desistirse de ella (art. 268). Estas formalidades varian: si se trata del Procurador General de la República deberá recabar Resolución Suprema que lo autorice a practicar tal acto procesal (art. $2^{\circ} .8489,30$ Set. 1936 y art. $5^{\circ}$ del Reglamento de $1^{\circ}$ de Octubre de $1951 ; y, 3^{\circ}$ ) en general, que no valen los actos en que el representante se excede en sus facultades (art. 368).

La representación termina -art. 28- en caso de vacancia del cargo, siendo sus efectos los ya indicados.

Representante de la mujer cosada-El marido ejerce en juicio la representación de su mujer, según el art. 20 del C. de P. C.: -"EI marido ejerce en juicio la representación de la mujer, salvo las excepciones que establece la ley".

Sabemos que el fundamento de esta regla está en la necesidad de dirección que como toda sociedad tiene también la familia. Además es entidad de tal naturaleza que por el número de sus miembros correría el riesgo de no poderse tomar una decisión si los cnóyuges no estuvieran de acuerdo.

El actual C. C., ha concedido a la mujer casada la capacidad para comparecer en juicio (art. 172). Esto significa que, rectificando la legislación anterior, se le ha concedido la capacidad procesal plena y por lo mismo ha quedado comprendida dentro del art. $1^{\text {o }}$ del C. de P. C.

Es preciso concordar esta disposición con las que existen al respecto en el C. de P. C. (arts. 20 al 25). El C. C., reconoce a la mujer casada facultad de comparecer en juicio por lo tanto sin licencia del marido, cuando se trata de sus bienes propios, no de los comunes de la sociedad cenyugal, desde que según el art. 188 del C. C., el marido es el administrador de los bienes comunes y tiene las facultades de tal, entre ellas la de representar en juicio que atañe $\alpha$ los bienes de esta calidad. 
Pero si no hay sino bienes propios $y$ comunes $y$ los primeros están representados por la mujer en las acciones relativas a los que le pertenece y los segundos por el marido, por ser administrador de la sociedad conyugal, resulta que la representación de la mujer casada que establece el art. 20 del C. de P.C., queda reducida a la que ejerce el marido solo en los casos en que la mujer no disponga otra cosa en cuanto a sus bienes propios $y$ por lo mismo teniendo su origen en la voluntad de la mujer no constituye propiamente una representación legal. Solo puede admitírsele como tal en cuanto la representación no requiere del instrumento de poder.

La representación de la mujer por el marido está sujeta a las siguientes reglas:

Primera regla.-La representación legal de la mujer casada se refiere a los casos en que es necesaria esta representación; resultando que conforme al actual C. C., la representación por el marido de la mujer casada no es necesaria ni obligatoria en ningún caso; es solo facultativa de la mujer.

Segunda regla. - Notemos que la representación del marido apesar de no ser obligatoria, sino facultativa, en los casos en que se ejerza, el marido no necesita acreditarla con poder alguno, le basta acreditar su calidad de esposo, según lo ha establecido acertadamente la jurisprudencia nacional y lo consagra el Anteproyecto del C. de P. C., en su art. 56.

La tercera regla contenida en el C. de P. C. al respecto, se refiere $\alpha$ que la mujer para comparecer en juicio, requiere autorización del marido o en su defecto autorización judicial.

La autorización del marido debe constar por escrito y puede otorgarse por escritura pública o mediante la firma del marido conjuntamente con la de la mujer en el recurso por el cual se apersona al juez por primera vez, dentro de un proceso determinado.

La autorización del juez, no determina el C. de P. C., cómo ni en qué caso puede obtenerse pero es indudable que tendrá que tramitarse con audiencia del marido. En caso de oposición de éste requiere licencia judicial.

Más éstas disposiciones han quedado derogadas por el C. sustantivo al otorgar capacidad procesal plena a la mujer casada.

La cuarta regla del C. de P. C., es que por excepción la mujer casada no requiere licencia del marido ni la cutorización judicial en los casos del art. 22. Este ha quedado derogado también por lo menos en parte por el C. C.

El art. 22 señala los casos en los que la mujer casada puede litigar sin licencia marital ni judicial $y$ casi no requieren ningún comentario.

El inc. $1^{\circ}$ se refiere al caso de que esté divorciada. El divorcio pone fin a la sociedad conyugal. Como la existencia de ésta es la única razón de la representación marital, desde que es una de las facultades comprendidas dentro de la potestad marital, es claro que al terminar la causa termina la consecuencia, o sea la representación del marido.

Debe notarse que no se refiere el inciso a la simple separación de hecho de los cónyuges, sino que se requiere separación judicial. 
El inciso $2^{\circ}$ se refiere al caso de que sea el marido con quien va $\alpha$ litigar la mujer en cuyo caso es obvio que no se requiera licencia de éste.

El inc. $3^{\circ}$ se refiere al caso de que la materia del pleito sean acciones $u$ obligaciones provenientes de la industria o profesión que la mujer ejerce conforme $\propto$ las leyes. El derecho comercial (arts. 6 al 12 del C. C. de), señala los requisitos para que la mujer casada pueda ejercer el comercio. Debe de tenerse en consideración que la mujer casada sólo tiene personería para comparecer en juicio por cuestiones provenientes de su industria, si la ejerce conforme a las leyes esto es con las formalidades legales para ejercer éstos actos. En verdad estas formalidades legales constituyen una manifestación expresa o tácita de la voluntad del marido de que su mujer pueda comparecer en juicio en esos casos.

El inc. $4^{\circ}$ al autorizar a la mujer casada para apersonarse cuando el objeto del juicio sean acciones que deriven de la administración de sus bienes parafernales, esto es de sus bienes, propios (arras y parafernales) es innecesario desde que conforme a la ley sustantiva la mujer casada tiene la administración de tales bienes. En el C. C.. de 1936, se han equiparado dentro de la denominación de bienes propios de la casada, las arras y los bienes parafernales del C. C. de 1952 .

Por último el inc. $5^{\circ}$ permite a la mujer casada comparecer en juicio en los juicios de desahucio o pago de arriendos con las condiciones: $1^{\circ}$ que la acción se refiera a la casa que habita; $2^{\circ}$ que el marido se encuentre fuera del lugar.

Este es el único caso de los contemplados por el art 22 que ha quedado subsistente después de la reforma del C. C.

La razón de este precepto es doble: $1^{\circ}$ se establece por la naturaleza simple de esta clase de acciones, favoreciéndose así al propietario o demandante que tiene con quien ventilar la acción en el propio lugar del juicio; $2^{\circ}$ porque el Comité de Reforma Procesal estimó que la condición de inquilino corresponde tanto al marido como a la mujer.

Pero debe notarse que esta representación no se admite sino con ciertos requisitos: $1^{\circ}$ se limita a los juicios indicados de desahucio y pago de arriendos. En la práctica se ha visto proceder también en los juicios de aviso de despedida que sirve para poner fin a los contratos de locación-conducción sin plazo tijo, sin duda porque según el C. de P. C., estos últimos juicios se siguen por los trámites de los juicios de desahucio, deduciéndose de aquí que le es aplicable la regla que estudiamos.-2 $2^{\circ}$ las acciones deben referirse a la casa que ocupa la mujer. Esto es que sería improcendente si se tratara de casa que sub-arrienda o de la acción de pago de arriendos atrasados de una localidad que ya la mujer ha desocupado dejándolos impagos.- $3^{\circ}$ que el marido no se encuentre en el lugar del juicio.

La jurisprudencia ha determinado el alcance de esta disposición, on el sentido de que siempre que no se reuna este requisito de ausencia del marido, aunque la mujer haya celebrado el contrato de arrendamiento $y$ viva separada del marido, la demanda debe entenderse con éste.

$6^{\circ}$-La quinta regla es la del art. 24 que permite a la mujer demandar al marido por los derechos que corresponden a sus hijos...-Es obvio que en. 
cualquier caso en que tenga que litigar con el marido, no es posible exigir la licencia de éste...

Esta materia ha sutrido modificaciones en el texto del Anteproyecto del C. de P. C., debido a la reforma de la ley sustantiva. - La reforma sólo propone la excepción en el caso de que la mujer demande al marido en defensa de los derechos que corresponden a los hijos. Este principio ya había sido admitido por la jurisprudencia, limitada al caso de los alimentos. Pero ha eliminado el caso del inc. $5^{\circ}$ que acabamos de estudiar.

En los casos en que la mujer tiene capacidad para comparecer en juicio, puede hacerlo por sí misma o por apoderado, pues conforme al art. 25: "Las mujeres casadas pueden hacerse representar en juicio por medio de apoderado, en los casos que pueden comparecer por sí mismas". Es la aplicación de la regla general del art. $1^{\circ}$ del C. C.

Extsnsión de las facultades del marido como representante legal de la mujer, conforme al art. 27: "La amplitud de la representación de los: "personeros legales de que se ocupa este capitulo, es la que confiere "el poder general para pleitos".

(Ejercen ademós, tales personeros, las facultades para las cua"les se requiere en juicio poder especial, salvo las prohibiciones ex"presas de la ley y la observancia de las formalidades que ella es"tablece".

El marido tiene las facultades que corresponden al poder general para pleitos $y$ además las facultades para las que se requiere poder especial. pero de estas últimas facultades, unas no puede ejercer, otras sólo puede bacerlo con determinadas formalidades; $\mathrm{y}$, otras libremente.

De ésto resulta que el marido: 1 - -sólo podrá ejercitar aquellas que no están expresamente prohibidas por la ley, así no podrá adoptar, emancipar, etc. y demás que establece la ley sustantiva con el carácter de actos personalísimos. $2^{\circ}$-Otras facultades del poder especial podrá ejercer con ciertas formalidades. Estas son las que se enumeran en el art. 21; "No. puede el marido convenir en la demanda, transigir, prestar juramento decisorio ni diferix a él, en los juicios en que sea parte su mujer, sino con el consentimiento de ésta, manifestado en escritura pública o escrito presentada al juez y con firma legalizada".

Todos estos actos sólo pueden ser realizados con el consentimientoexpresado en forma auténtica e indubitable. La razón es que se trata de actos de disposición evidente. Para ello tiene que aparecer el consentimiento de la mujer manifestado por escritura pública o por escrito presentado ante el juez de la causa y con firma legalizada.

3-Todgs las demás facultades del poder especial puede ejercerlos libremente el marido.

En el caso de que ejerza la representación con poder expreso de la mujer, el marido tiene las facultades que ésta le otorga y siendo su apoderado no rigen las leyes que se refieren a los representantes legales. 
Representanies legales de los incapaces

Art. 26: "Los menores o incapaces sujetos a patria potestad o some"tidos a guardaduría, serán representados en juicio por el padre o el "guardador".

Tienen que distinguirse las dos clases de incapaces por minoridad y por cualquiera de las otras causas que la ley sustantiva establece en los arts. 7 y 8 del C. C.

Los menores de edad tienen como representantes legales a sus padres o tulores, es una consecuencia de la patria potestad o de la guarda. - Esta regla se descompone así: los hijos menores están representados en juicio por el padre que ejerce la patria potestad. Luego si por razón de divorcio o separación se ha confiado la guarda de los hijos a la madre, ésta tiene su representación. En los casos de que los padres por cualquier causa hayan perdido el ejercicio de la patria potestad o que hayan muerto, la representación la ejerce el tutor. Si se trata de expósitos ésta corresponde al jefe del establecimiento donde se encuentran.

Los mayores incapaces están representados en juicio por sus curadores según lás disposiciones del C. C.

\section{Extensión de sus facullades.}

La extensión de sus facultades es la que determina el art. 27.Aplicado a este caso el representante no puede sin ciertas formalidades: desistirse de la acción (art. 268); convenir en ella (art. 323), ni puede prestar confesión más allá de sus facultades (art. 368); ni prestar juramento decisorio o deferir al del contrario, (arts. 384 y 368 del C.P.C.)

Las formalidades varian según se trate de padres 0 de tutores $y$ curadores. En el primer caso los incs. $6^{\circ}, 12^{\circ}$ y $13^{\circ}$ del art. 522 del C.C. sólo exigen autorización judicial, que se decidirá previa audiencia del ministerio Fiscal. - En el segundo caso se exigen mayores formalidades por razones obvias, la autorización judicial se pronuncia previa audiencia del consejo de familia, si no tiene padres el representado y conforme a los arts. citados 523 y 1312 del C.C.

En cuanto a la terminación de la representación se aplica la regla ya establecida del art. 28.

\section{REPRESENTANTES DE AUSENTES}

El último capítulo del título primero de la sección primera del C. de P. C., trata de la materia del rubro.

Conforme al C. C., son incapaces los desaparecidos cuya ausencia está judicialmente declarada. El concepto de ausencia ha quedado así precisado como persona que ha desaparecido del lugar de su domicilio, cuyo paradero se ignora y cuya supervivencia es incierta. 
Es evidente la necesidad de que éstas personas sean provistas de un representante.

Esta es una de las materias en que más se requiere la concordancia con los preceptos del Código sustantivo, posterior al Código Procesal.

Personcrs que ejercen la representación de los cusentes.-Art 29\%:

"A falta de apoderado o por insuficiencia del poder, representan en "juicio al que se ha separado o ha desaparecido del lugar de su "residencia o domicilio y cuyo paradero se ignora, las personas si"guientes, en el orden que aquí se establece: $1^{\circ}-\mathrm{E}$ cónyuge, con "excepción del que está divorciado, y de la mujer que hubiese aban"donado la casa conyugal o incurrido en adulterio judicialmente de"clarrado;

"2 2 - -los hijos;

" 3 -el padre $y$ en su defecto la madre;

" 4 - -la persona que nombre el juez.

Hay a este respecto la cuestión de si el C. C. de 1936 ha variado o no el régimen $y$ las disposiciones del C. de P. C.

Según el C. de P. C.. las personas que ejercen la representación de los ausentes se denominan representantes de ausentes $Y$ se les designa conforme el orden establecido en el art. 29, complementado por los arts. 30 al 33.

El C. C., en su art. 597, otorga la representación de los ausentes en juicio, a los curadores del ausente y las personas que deben ejercer tal representación estón indicadas en los arts. 559 al 563., aplicables según el art. 590 del Código sustantivo.

Pueden adoptarse dos posiciones: 1) el C. C. no ha derogado las disposiciones del C. de P. C., porque a pesar de ser de una ley sustantiva y otra procesal, para algunos adjetiva, no hay oposición entre ambas. Pueden así existir los representantes del ausente y los curadores de bienes del ausente, que el C. C. de 1852 llamó guardadores. La diferencia entre el representante del ausente y curador del ausente estaría en que el primero es sólo su personero en juicio $y$ el segundo es además administrador de sus bienes.

2) otra posición: el C. C. ha derogado y modificado las disposiciones del C. de P. C., sobre la materia que nos ocupa reemplazando al representante por el curador y alterado el orden del llamamiento al cargo y la forma de su designación

La Comisión Reformadora del C. de P. C. que ha recogido en el Anteproyecto formulado las modificaciones del C. C., para introducirlas en el Código Procesal unificando y concordando las disposiciones de ambos cuerpos de leyes, según se lee en la nota de remisión del Anteproyecto al Ejecutivo, ha demostrado este mismo criterio, pues en su capítulo IV de la sección I, establece expresamente que la representación la ejerce el curador de bienes Sin embargo parece que lo exacto no es ni uno ni lo otro. Las normas del C. de P. C. han quedado como subsidiarias para los casos en que no se haya proveído a la representación del ausente por medio de 
un curador de bienes o no existiesen bienes, debiendo sólo tener la representación de la persona.

Por eso es interesante establecer la comparación entre ambos regímenes establecidos por el art. 29 del C. de P. C. Y por los arts. 559 y 363 del C. C.. aplicables a los ausentes según el artículo 590 .

Las discrepancias son éstas:

a) en cuanto al orden del llamamiento a la representación porque a continuación del cónyuge (inc. $1^{\circ}$ del art. 29) se llama por el C. de P. C.. a los hijos mientras que el C. C. lo hace a los padres (inc. $2^{\circ}$ del art. 559) Es discutible la justificación de esta modificación desde que los hijos son heredados de un orden superior a los padres del causante, tienen interés anterior $\alpha$ éstos últimos en los bienes del padre ausente.

b) el C. de P. C., declara que es improcedente la representación por el cónyuge no solamente en los casos de divorcio legalmente pronunriado sino también en el caso de la mujer que ha abandonado el hogar conyugal o incurrido en adulterio judicialmente declarado. El C. C. únicamente excluye a la mujer en el caso de separación judicial. También estimo que la reforma es muy discutible en cuanto al caso de abandono.

c) Llama el C. de P. C., de entre los padres, primero al padre y sólo en defecto de éste a la madre, lo que no hace el C. C., inc. $2^{\circ}$ del art. 559, aunque es presumible desde que el marido ejerce a su vez la representación de su mujer. Parece que el C. de P. C.. ha procedido así en calidad de reglamentación del C. C., aclarando sus preceptos.

d) respecto a los descendientes, establece el C. C. -inc. $3^{\circ}$ art. 559-, un criterio judicial para distinguir entre los de igual grado.

e) El C. de P. C., sólo llama a los hijos, el C. C. a los descendientes en general, prefiriéndose al más próximo al más remoto.

f) El C. C. -inc. $4^{\circ}$ art. 559-, designa después de los descendientes a los ascendientes no padres, lo que no hace el C. de P. C. que a falto de los padres llama al extraño que designe el juez.

g) El C. C. ha suprimido el inc. $4^{\circ}$ del ort. 29 pues la designación de una persona no indicada expresamente en los incisos anteriores, la hace ya no el juez, sino el Consejo de familia, según el art. 563 del C. C.

Designación del representante por los parientes del causante.-Para los casos en que debe hacerse la designación por los parientes el C. de P. C.. señala tres reglas consignadas respectivamente en sus arts. 30,31 y 32 .

La primera regla en el art. 30 , es que si hay varios hijos corresponde la representación al que designe la mayoría. La segunda regla, art. 31, es que los hijos ilegítimos tienen el mismo derecho de representar al padre ausente con tal que estén reconocidos por él y no haya hijos legítimos. La tercera regla, art. 32 , que para los efectos de la representación se considera entre los hijos, al representante del hijo menor de edad o incapaz y al marido de la hija.

Pero las prescripciones del Código sustantivo en esta materia, es- 
tablecen que en cuanto a la designación del curador, conforme a los incs. $3^{\circ}$ y $4^{\circ}$ del art. 559, el juez es el que decide en los casos de varios descendientes y ascendientes, y no la mayoría.

El juez ejerce esta facultad en forma tasada porque debe decidir oyendo previamente al Consejo de Familia y debe hacerlo prefiriendo al más próximo al más remoto، y entre los de igual grado al más idóneo. Sólo en este último caso, propiamente, funciona el arbitrio judicial.

Designación por el juez del representante del cusente. - Conforme al C. de P. C. vigente el juez hace la designación en éstos casos: 10cuando no se reúne la mayoría necesaria para la designación por los interesados 0,2 - -en rebeldía de éstos, según el art. 30: "Si hay varios hijos, corresponde la representación al que designe la mayoría o el juez a falta de esa mayoría o en rebeldía de los interesados".

Lugar de nombramiento -Art. 39- "La designación o nombramiento de la persona que debe representar en juicio al ausente, se haró por el juez del último domicilio o resídencia del cusente, a petición de cualquiera persona o del Ministerio Fiscal, previa notificación por el periódico durante quince días y a mérito de los esclarecimientos que el juez crea convenientes".

El juez que debe intervenir es el del último domicilio del ausente $y_{\text {. }}$ a falta de éste, por ser simplemente transeúnte, el juez de su simple residencia.

La petición puede formularse por cualquier persona que tenga interées en la designación, de tal manera que puede ser un pariente o un acreedor, o cualquiera que tenga interés que se provea a la representación del au-sente. También a petición del Ministerio Fiscal.

Previa publicación de avisos por 15 días, con las investigaciones. que el juez crea convenientes y la reunión del Consejo de Familia en su caso, se hace el nombramiento.

Obligaciones del representante del ausente.-Debe representarlo en juicio, debiendo distinguirse varios casos:

1.-jujcios que dejó pendientes el cusente. - En este caso el representante está facultado para continuarlos según el art. 33: "las personas

"designadas en los artículos anteriores $29,30,31$ y 32 , tienen la

"obligación de comparecer en el juicio que dejó pendiente el au-

"sente..." Sino se podría perjudicar los intereses del ausente quo tiene la única oportunidad de discutir el punto planteado, pleito que no puede quedar abandonado por el interés tanto del ausente, como de su contraparte en el juicio ya instaurado.

20-Juicios iniciados después que la ausencia se produjo.-En ellos puede intervenir el representante:

a) como actor en estos casos: $1^{\circ}$ - Si el ausente aparece con un interés común o coadyuvante al actor; $2^{9}-\mathrm{Si}$ el representante obtiene licencia judicial salvo que se trate de acciones provenientes de la simple administración, conforme al art. 35 . 
"El representante del ausente no podrá entablar demandas sin auto"rización del juez, salvo las de tercerías, cobranzas de arrendamien"tos, desahucios $Y$ demás relativas $\alpha$ actos $Y$ contratos de mera ad"ministración".

b) como demandado si tiene un interés común o coadyuvante al demandado sólo en el caso de haber transcurrido seis meses desde las últimas noticias del ausente, pues el art. 34 establece;

"Para que los representantes del ausente estén obligados a compa"recer en juicio nuevo en que el ausente sea demandado, 0 en "que aparezca con un interés común y coadyuvante al demandado. "es necesario que hayan transcurrido seis meses desde las últimas "noticias del ausente".

Amplitud de esta representación. - Es la que determina el art. 27 del C. de P. C., esto es, la del poder general para pleitos comprendiendo además las facultades especiales previas ciertas formalidades.

Fin de la representación de los ausentes.-El C. de P. C., en el art. 38 se refiere a la terminación de la representación del ausente por acto voluntario del representante, esto es, por renuncia de éste. Establece que puede producirse después de tres años do las últimas noticias del ausente. Es el caso de renuncia del poder y es facultativa. - También puede producirse por cesación en el cargo, sea porque reaparece el ausente, es subrogado, o en los casos del art. 36.

Pero el que ha dejado apoderado no es jurídicamente considerado ausente. Además el C. de P. C., está tratando no de los apoderados sino do los representantes legales de los ausentes. Este preciepto debe ser ubicado en todo caso dentro del capitulo que trata de los mandatarios judiciales, pues no puede presentarse el supuesto de hecho desde que ausente es la persona que desaparece de su domicilio, sin dejar un representante.

También puede terminar la representación por actos ajenos al reprecentante, en los siguientes casos:

10-Por reaparecer el ausente, desde que automáticamente entonces cesa el estado de ausencia.

2 -Cuando se nombra guardador de los bienes del ausente, según los Arts. 1272 y siguientes del C. de P. C., lo que procede después do un año sin noticias del desaparecido.

$3^{\circ}$-Cuando se otorga la pasesión provisional de los bienes del ausente según los arts. 1284 y siguientes del C. de P. C., ésto es después de 10 años de las últimas noticias del deaparecido.

4:-Cuando se dá la posesión definitiva.

$5^{\circ}$-Cuando se agotan los bienes del ausente, según el art. 614 del C. C.

Pero conforme al Código Civil de 1936, han desaparecido estos diver. cos estados de ausencia, no se ha dejado subsistentes sino dos: 
1) el de nombramiento de curador de los bienes - art. 596-; Y.

2) el de posesión definitiva a los 10 años, desde las últimas noticias del ausente $o$ el transcurso del tiempo necesario para que haya cumplido 80 años de edad -ant. $611-$ y de 3 años en caso de ausencia calificada -art. 612-. Estos preceptos establecen expresamente que en estos casos termina el cargo de curador del incapaz.

Efectos de la terminación de la representación. - En todos los casos en que se produce por motivo de muerte $\circ$ incapacidad del representante se suspende el procedimiento que se seguía con su intervención, hasta que se haga nueva designación.

\section{CAPITULO II}

\section{IA COMPETENCIA EN EI C. DE P. C.}

En el análisis del juicio ordinario en su primera etapa, ésto es la demanda, deben considerarse quiénes pueden interponerla, ante quién $y$ cómo deben entablarla. En el capítulo anterior se ha expuesto las regías atinentes a la comparecencia.

En el presente capítulo vamos a tratar del segundo punto o sea ante quién debe interponerse la demanda, esto es de la competencia, de sus reglas y de los recursos que la ley tranquea en garantía de las mismas, conforme a la doctrina y la legislación nacional.

Esta materia está tratada en los arts. 40 al 73 del C. de P. C., pero antes de entrar al estudio de su texto conviene recordar algunas nociones al respecto.

Concepto de competencia. -Etimológicamente viene de competere lo que toca o corresponde. En este caso se podría decir que es lo que toca y corresponde juzgar a determinado juez. Además hay varias acepciones de competencia. Una acepción impropia según la cual se entiende por competencia el conflicto entre dos jueces, cuando ambos pretenden tener facultad para conocer de un mismo asunto, o ninguno cree tenerla, siendo empleado así como sinónimo de contienda de competencia ya sea positiva - negativa, respectivamente. Según la otra acepción propia o estricta competencia en el asunto determinado es la aptitud de un juez para conforme a ley, ejercer los atributos de la función jurisdiccional de que estó investido.

Así pues, es bien conocida la diferencia entre jurisdicción o sea facultad de conocer, tramitar y decidir los conflictos y competencia, el límite del poder jurisdiccional, género y especie respectivamente. Por lo cual to: dos los jueces por ser tales tiene jurisdicción pero no todos tienen compotencia para conocer un asunto determinado. La competencia se ejerce sobre las causas en las que según la ley, el juez, ejerce su jurisdicción en forma perfecta y correcta.

Contra muy autorizada opinión creemos que la relación tradicional entre jurisdicción $y$ competencia como género $y$ especie es exacta desdo 
que la competencia supone la jurisdicción y ésta la comprende. El género es la noción universal que representa una parte de la esencia común o varias especies, el poder juridiccional dividido entre los diversos jueces, constituye la competencia.

Esta limitación del poder jurisdiccional está impuesto por diversas razones, la extensión territorial, la jerarquía de los jueces, etc.

Los elementos que determinan la competencia son: l) El territorio. La razón práctica de que los jueces deben estar en las diversas circunscripciones del territorio de un Estado, determina que se fije su competencia dentro de determinados linderos.

2) La naturaleza del asunto. Fundado en el principio de la división del trabajo y las ventajas de la especialización.

3) El monto de la causa. Aunque todos los derechos requieren de las mismas garantías es claro que los juicios económicamente menos importantes, no requieren jueces con mucha experiencia ni deben soportar grandes gastos, pues generalmente por lo menos, no son muy complicados, $y$ así de eilos pueden ocuparse jueces con menos requisitos y con determinadas y suscintas reglas de procedimiento. Entre nosotros conforme el C.P.C., cuantía los juicios se clasificaron según no sobrepasaran de S/.. 500.00 ó si sobrepasasen de ésta suma. En el primer caso la competencia correspondía a los Jueces de Paz y en el segundo a los Jueces de Primera Instancia. Hoy en virtud de la ley $\mathrm{N}^{\circ}$ 13036, son de competencia de los Juzgados de Paz los juicios cuya cuantía no sobrepasa la suma de $\mathrm{S} /$. 1,200.00.

4) El grado; la competencia se determina por las diversas instancias superiores e inferiores. Instancia es la etapa de prosecusión de un juicio o recurso desde que se interpone hasta que se decide, y está marcada desde la interposición de la demanda o de los recursos de apelación y nulidad, hasta que se resuelvan por el mismo juez ante el cual se tramitan. Los juicios deben iniciarse en Primera Instancia que está constituída por los jueces de Primera Instancia subiendo en escala a las Cortes Superiores o Segunda Instancia y Corte Suprema que a veces procede como Tercera Instancia.

Pero hay excepciones. Entre nosotros el procedimiento de legitimación por declaración judicial se entabla en Segunda Instancia, ésto es ante la Corte Superior; y los juicios de revisión que permite la ley de Accidentes de Trabajo se interponen ante la Corte Suprema, aunque sólo para la determinación de la procedencia o improcedencia de la revisión.

5) El tiempo de la interposición de la demanda; se constituye la competencia por el turno, establecido para la mejor repartición del trabajo entre los diferentes jueces competentes para conocer de un mismo litigio.

Todos estos elementos sirven en nuestra legislación para la determinación de la competencia según aparece de los Arts. 40 y siguientes del C. de P. C.

$\mathrm{El}$ orden en que éstos elementos funcionan para la determinacjón de la competencia es el antes indicado. Así si queremos saber qué juez es 
competente para conocer de una demanda civil de cobro de una suma de dinero ascendente a S/. 5,000.00 debe atenderse: $1^{\text {9}}$ ) Al lugar donde debe interponerse, conforme a las reglas que se estudiarán. Resultando por ejemplo, que corresponde a Lima, Jébese en $2^{\circ}$ lugar considerar la naturaleza de la causa y como es civil, corresponderá al Juez de Faz o de Primera Instancia y no al Juez Instructor de esta Capital.

$3^{\circ}$-Como hay varios jueces civiles al inferior, ésto no a los jueces que forman Tribunales de alzada:

4.-Entre éstos o entre los jueces de Paz y de Primera Instancia se determiná la competencia. atendiendo a la cuantía del pleito y como en el ejemplo se supone mayor de $\mathrm{S} / 0.1,200.00$, corresponderá a los jueces de Primera Instancia; $y$

50-Como hay varios jueces de Primera Instancia, es competente el que está de turno en el momento de la interposición de la demanda.

La defectuosa apreciación de estos elementos produce o determina la incompetencia del Juez. Pero unos elementos son renunciables por las partes y otros no. Los elementos de naturaleza, grado, monto de la causa Y turno, están establecidos de conformidad con la organización del Poder Judicial, y por lo mismo constituyen leyes de orden público que no son renunciables (competencia absoluta) y contra las cuales no vale la voluntad de las partes.

En cambio, la territorialidad, o sea la división de la competencia por razón del territorio, se ha establecido por una razón práctica, en beneficio de los propios litigantes, y por eso éstos pueden renunciar $\alpha$ éste beneficia, esta es la que constituye la prórroga de la competencia (competencia relativa).

La competencia se decide por el actor al interponer la demanda; por el demandado al contestarla sin declinar jurisdicción y por el juez en dos ocasiones: al admitir la demanda y al resolver la excepción de incompetencia.

Reglas para la determinación de la competencia.- Nuestro C. de P. C. señala dos principios para la determinación de la competencia: uno principal y otra subsidicrio. Son éstos en primer lugar la sumisión voluntaria de los interesados $\alpha$ un juez determinado; es competente el juez al que las partes han sometido el asunto y $\alpha$ falta de éste acuerdo en segundo lugar, por lo tanto, rige el principio de que es juez competente el del domicilio del demandado

Estas reglas fundamentales para la determinación de la competencia y el orden de prelación entre ellas aparecen de los Arts. 40 y 44 del C. de P. C.

Pero estrictamente hay otros principios también adoptados por nuestro Código Procesal para la determinación de la competencia, en forma excepcional o concurrente y optativa. Son éstos el fuero real o sea la competencia del juez por el lugar donde están las cosas materia de litigio, que se admite en los incisos $2^{\circ}$ y $4^{\circ}$ del Art. 45. El forum contractus, fuero contractual, o sea el lugar señalado para el cumplimiento de la obligación, en el inc. $1^{\circ}$ del Art. 45. El forum gestae administracionne, o lugar donde 
se desempeña la administración,, por el inc. $3^{\circ}$ del Art. 45 y el fuero instrumental, lugar donde se encuentran las pruebas, en el Art. 46.

10 Reglas de la competencia determinada por la sumisión de los litigantes:- Art. 40.

El Art 40 del C de P. C., establece la regla de que es competente para conocer del juicio, el juez a quien los litigantes se hubiesen sometido expresa o tácitamente Pero esta sumisión sólo puede tener lugar respecto de jueces a quienes corresponde el conocimiento de juicios de la clase y cuantía del que se trata, esto equivale a decir que cabe el sometimiento a diferente juez del que por razón de la competencia territorial le corresponde el conocimiento del caso.

El principio está perfectamente justificado desde que como ya so ha indicado la división del territorio en circunscripciones territoriales, solo obedece al propósito de favorecer a los litigantes para que sean atendidos dentro de la circunscripción que hay que suponer más le conviene por diversas causas, pero el interesado puede renunciar a este beneficio; con ello en nada se alteran las leyes de la organización judicial de un país.

Esta sumisión constituye lo que se llama indebidamente la prórroga de la jurisdicción, confundiendo éste concepto con el de competencia (1) por la que los litigantes conceden aptitud para conocer de un asunto determinado, $\alpha$ un juez que normalmente no la tenía. Su fundamento, repito, está en tratarse de un elemento renunciable.

Requisitos de la prórroga de la competencia. - Manifestación de dicho sometimiento. Para que sea válida se exige la capacidad general. Esta manifestación (Ant. 40), puede revestir dos formas: expresa o tácita. Cada una sujeta a diversas reglas.

Sumisión expresa.- Sus requisitos son: a) un acto inequívoco de la voluntad de las personas, esto es indicar con precisión la voluntad de que el asunto sea conocido y decidido no por el juez a quien correspondería normalmente sino a uno distinto, dentro de las limitaciones que luego se estudia. rán. Por lo tanto no puede en esta forma aparecer sino de un convenio (3). La prórroga unilateral podría admitirse sólo como una renuncia que una persona hace del fuero que le corresponde a favor del fuero de otra persona con que tiene una relación jurídica. El beneficiado al no hacer valer los recursos pertinentes cierra el contrato.

b) Está sujeta a la condición de que se refiera a jueces de la misma clase y cuantía del asunto de que se trata, conforme al Art. 40. que luego glosaremos.

(1) Alzamora.- D. Procesal Civil, pág. 98.

(2) De la Plaza. - Derecho Procesal, pág. 238.

(3) Prieto. - Tratado de Derecho Procesal, pág. 512. 
c) Supone por lo dicho una forma escrita. No tiene que revestir. una formalidad especial.

d) En cuanto a su contenido, basta que en ella conste de manera inequívoca, la voluntad de prorrogar la compretengia. Generalmente se expresa asi: "renuncia al fuero de su domicilio y se somete expresamente a los jueces de tal lugar para todo lo concerniente a éste contrato".

Basta así la designación de domicilio convencional en ejecución de la facultad que concede el Art. 27 del C. C.. para que se haya producido la prómoga de la competencia, como lo indica tal precepio legal. En cuyo caso no es necesaria la expresa renuncia del fuero del domicilio, como se exige en el Código Español, (1) sino que basta la constitución de un domicilio especial para las cuestiones que atañen a ese contrato.

Cuando una persona se somete a la competencia de un juez especial, mediante el simple señalamiento de domicilio, puede ser emplazado ante ese juez aunque normalmente no le corresponda por razón del territorio, pero deberá ser notificado en la casa donde habita aunque ésta quede dentro de otra jurisdicción, pues no significa la derogatoria de las leyes procesales al respecto.

Sumisión tácita.- Cabe también según el Ant. 40.- Constituye la presunción de la voluntad de someterse a una competencia particular.

Esta sumisión sólo puede tener lugar respecto del juez a quien corresponde el conocimiento de los negocios de la misma clase y cuantía.

1) Se opera para el actor (Art. 43), por el hecho de interponer la demanda ante determinado juez.

Para el demandado se produce la présunción de la prórroga tácita, cuanto realiza cualquier acto procesal que significa tal sometimiento, $y$ según el Art. 44 por contestar la demanda o por no hacer valer los recursos que la ley franquea para evitar la intervención de un Juez incompetente, esto es, sin deducir la excepción declinatoria de jurisdicción, según el C. de P. C., o sin solicitar que se entable la contienda de competencia.

Se funda la presunción en que tanto el demandante como el demandado conocen la incompetencia y apesar de ella se someten al Juzgado, pero podría presentarse el caso de que lo hacen por ignorancia de la incompetencia. En este caso el procedimiento es sin embargo válido, no por una ficción (2), sino porque se trataría de un error de derecho que no puede invalidar el acto.

2) Solo procede respecto de jueces a quienes en general corresponde el conocimiento de los asuntos de la misma clase y cuantía del que se trata, según la segunda parte del Art. 40, del C. de P. C.

Esto es, no cabe la disposición de la competencia absoluta, (competencia objetiva por la naturaleza de la causa $y$ funcional por la organización del proceso indicado), sino únicamente de la competencia relativa. (competencia territorial).

(1) Prieto. - Ob. cit. - Pág. 512.

(2) Prleto. - Ob. cit. - Pág. 510. 
Unicamente cabe la prórroga de la competencia territorial por cuanto está creada en beneficio de los litigantes, pero no de los otros elementos de la competencia, vinculados a intereses públicos, $Y$ por lo mismo indeclinables por las partes.

En consecuencia no podrá prorrogarse la competencia de un Juez de Primera Instancia, para conocer de una instrucción; ni a la Corte Suprema para conocer en Primera Instancia, ni al Juzgado de Trabajo para intervenir en un juicio ordinario. Pero se puede prorrogar la competencia de un Juez de Primera Instancia de Lima, para conocer de un asunto que le toca conocer al Juez de Primera Instancia de cualquier otro lugar de la República.

El precepto que comentamos se refiere especialmente a la cuantía. Así que $\alpha$ un Juez de Primera Instancia no puede prorrogársele la competencia para conocer de asuntos cuyo monto no sobrepase a la suma de $\mathbf{S} /$. $1,200.00$.

Sin embargo esta regla no es absoluta. Encontramos en nuestra legislación estas excepciones: 1). No puede anularse lo actuado a pedido de parte si se ha sequido como juicio de mayor cuantía el que era de menor cuantía, pero si en el caso inverso (Ant. 304 del C. de P. C.); 2) Puede interponerse reconvención en el juicio ordinario, aún cuando la cuantía de ésta no sobrepase la de S/. 10.000 .00 (Art. 327 del C. de P. C.)

Se puede considerar que en ambos casos hay una prórroga tácita de la competencia desde que no se ha deducido la excepción de naturaleza de juicio ni declinatoria de jurisdicción en el primer caso; $y$ en el segundo, se interpone por el reconveniente conte un Juez de Primera Instancia, una acción que corresponde conocer al Juez de Paz.

Ambas excepciones están justificadas, pero en el primer caso más bien se trata de una tramitación distinta y más amplia, pero no de diferentes Jueces, desde que el juicio de menor cuantía y el juicio ordinario se siguen ante el Juez de Primera Instancia.

3) La sumisión debe hacerse en Primera Instancia. -Art. 41- "La sumisión sólo puede tener lugar en Primera Instancia y determina la competencia del superior jerárquico".

La razón es obvia desde que se establece o por la interposición de la demanda o por su contestación sin declinar de incompetencia 0 sin intentar la contienda, todo lo que se produce en Primera Instancia.

Efectos de la prórroga de la competencia.- 1) Fija la competencia de manera necesaria, ésto es que no cabe llevar posteriormente el conocimiento de la causa a otro juez.- 2) Determina la competencia del superior jerórquico (Ant. 41, in fine). Así la competencia del Juzgado de Primera Instancia de Lima, señala la de la Corte Superior del mismo Distrito, para conocer de la alzada.

2. Reglas de la competencia determinada por el domicilio del demondado, Art. 44.

Cuando falta el sometimiento expreso o lácito es juez competente el del domicilio del demandado (Art. 44). Si el demandado tiene vario 
domicilios puede ser demandado en cualquiera de ellos, conforme al Art. 53, que a la letra dice:- "El que tiene domicilio en dos o más lugares, puede ser demandado en cualquiera de ellos. El que no tiene ninguno, puede serlo en el lugar en que se le encuentre".

Este fué el criterio seguido en Roma en sustitución al forum originis. (1). La regla actore signator forum rei, el actor sigue el fuero del demandado, tiene el carácter de general y como fundamentos la razón teórica de que el demandado está en la tranquila posesión de los bienes que se le reclama en la demanda y por lo mismo el actor, que no ha probado todavía su derecho, (2), debe ir a buscarlo en su propia jurisaicción; y, en la razón de orden práctico, de que las pruebas han de conseguirse y actuarse con mayores facilidades en el lugar donde el demandado ejerce sus actividades jurídicas.

Hay excepciones a esa regla del domicilio del demandado, a favor del domicilio del actor como el caso de demanda de alimentos, la que no consignó nuestro C. de P. C., sino la Ley 12061 de 30 de diciembre de 1953. que ya había consagrado la jurisprudencia, según la cual el demandante por alimentos puede seguir la acción ante el juez de su propio domicilio y no ante el juzgado del domicilio del demandado.

El domicilio a que se refiere el C. de P. C., es el mismo de que trata el Código sustantivo. Por esta razón en unos casos es el domicilio voluntario y en otros, el domicilio legal.

Desde el punto de vista procesal sólo cabe aclarar que entre nosotros conforme al Art. 24 de la Ley Orgánica del Poder Judicial "corresponde $\alpha$ los jueces de Primera Instancia de Lima conocer en Primera Instancia de los despojos que infiere el Gobierno y de las demandas que contra él se interpongan sobre derechos que hubiese violado o desconocido ejerciendo funciones administrativas". La Ley 8489 de 3 de Diciembre de 1936, que creó la Procuraduría General de la República en el Art. $5^{\circ}$ establece que estas demandas necesariamente deberán interponerse ante los jueces de la Capital de la República (2).

Ásí puede considerarse que el domicilio del Estado para el efecto de la competencia territorial, es Lima, desde que debe ser emplazado dentro de esta circunscripción. En los casos en que es actor, se rige por las reglas comunes (Art. $5^{\circ}$ - Ley 8489).

No requiere ninguna explicación el caso de una persona que tenga varios domicilios, pluralidad que hoy admite nuestro C. C.. la que puede ser demandado en cualquiera de ellos (Art. 53).

Algunos autores (3) opinan porque debe distinguirse el domicilio constituído por el establecimiento comercial del domicilio familiar, para establecer la diferente competencia según que se trata de uno $u$ otra $c a-$ lidad de acciones. Dentro de los sistemas que como el nuestro admiten la pluralidad de domicilios y tratándose únicamente del lugar donde la persona

(1) Romero. - Estudio de Legislación Procesal. - T. I., pág. 79.

(2) Alsina. - Ob. cit., pág. 523.

(3) G. Aparicio y G. S. - L. O. P. J., pág. 78.

(4) Salvat. - Parte General. - No 973. 
ejerce sus actividades jurídicas en general, la distinción carece de utilidad próctica y al contrario puede ser causa de complicaciones del proceso.

Reglas respecto de personas no domiciliadas. - Art. 53. - La ley no puede ignorar el caso de las personas que carecen de domicilio, es decir de los transeuntes. Ni puede tampoco dejar de establecer el fuero que a ellos corresponde. La regla contenida en el Art. 53, es que a ésta clase de personas se les emplaza ante el Juez de su simple residencia, ésto en del lugar donde se encuentra aunque le falte el ánimo de permanecer en él.

Determinación de la competencia por el tuero del cumplimiento de la obligación.- Art. 45, inc. 1‥- "No obstante lo dispuesto en el Art. 44, el demandante puede, a su elección, interponer la demanda ante el juez del lugar señalado para el cumplimiento de la obligación".

Consiste en establecer la competencia en razón del lugar señalado para el cumplimiento de la obligación.

Este fuero se funda en que la acción tiene la finalidad de que el deudor cumpla coactivamente la prestación que no ha cumplido voluntariamente (1) y por lo mismo el acreedor debe tener los mayores privilegios.

Hay que suponer además que así se evitan mayores sacrificios de tiempo y gastos desde que al señalarse por el contrato o la ley un lugar determinado, ésto indica que las partes tienen allí un centro de sus actividades.

La ley procesal habla de "lugar señalado", para el cumplimiento de la obligación. Este señalamiento puede ser convencional o simplemente impuesto por la ley material o sustantiva respecto a la forma del cumplimiento de las obligaciones. Las reglas generales al respecto estón establecidas en los Arts. 1250 y 1251 de nuestro C. C., según las cuales rige primero, el lugar designado por las partes para el cumplimiento de la obligación; $2^{\circ}$ y en defecto del anterior, el lugar que imponen las circunstancias, la naturaleza de la obligación (contrato de obra, etc.) y la ley: $Y$. $3^{\circ}$ subsidiariamente, el lugar del domicilio del deudor, y si éste ha mudado del domicilio designado puede exigírsele el pago en éste o en el nuevo. En todo caso pues se trata del lugar donde el acreedor puede exigir el pago de la obligación por la convención o por la ley.

Las obligaciones subsidiarias se rigen por las reglas de la obligación principal (Art. 48):- "Es juez competente en las demandas sobre obligaciones de garantia o complemento de otras anteriores, el que lo es para los juicios sobre la obligación principal".

Caso de mancomunidad de la obligación demandada.- Ant 49.En los casos de multiplicidad de demandados hay que distinguir: i) Si se trata de obligación mancomunada por razón de la cual se demanda $\alpha$ varios de los deudores, el juez competente es el del domicilio de cualquiera de ellos. Debe entenderse que se trata de solidaridad, ésto es del

(1) Prielo. - Ob. clt., pág. 498. 
caso en que la obligación es exigible en su totalidad a todos, o a cada uno de los deudores, lo que se produce por la convención o la ley.

2) Sino hay mancomunidad, el C. de P... C., se refiere a la man. comunidad simple o sea la mancomunidad a prorrata, en la que cada deudor lo es sólo por una parte de la obligación ante los demandados, hay que distinguir: $\alpha$ ) si varios demandados tienen su domicilio en un mismo lugar, el juez de la circunscripción en que está domiciliado el mayor número, es el competente; b) en todos los demás casos es competente el juez del domicilio de cualquiera de ellos.

39 Determinación de la competencia por el fuero rei sitcre. Inc. $2^{\circ}$ del Art. 45. - Cuando se trata de acción real o mixta, ésta debe entablarse ante el juez del lugar en que se encuentren las cosas o sea inmuebles que es materia de la acción real o mixta que motiva el pleito"..

"Si la acción versa sobre varios inmuebles o sobre uno solo, situados aquellos o éste en diversas jurisdicciones, es competente el juez de cualquiera de los lugares de ubicación".

Esto significa determinación de la competencia del Juez por el lugar donde se encuentre la cosa, sea o no inmueble, que es materia del pleito.

Así pues se clasifican las acciones en personales, reales y mixtas (1) atendiendo a la calidad del derecho invocado en las prestaciones y mejor $\alpha$ las prestaciones mismas (2), pues hay derechos reales como el usufructuo y el uso de los que nacen también acciones personales (3). Sabemos que para las acciones personales es competente el juez al que se han sornetido las partes o al juez del domiclio del demandado; para las acciones reales, éste último o el del lugar donde se encuentra la cosa, según el Art. 45, inc. $2^{\circ}$, pero además existe, aunque es muy discutida, la clase de acciones mix: tas, es decir en los que el actor tiene a la vez un derecho real y uno personal que puede ejercitarlos simultáneamente (4).

Su fundamento está en la presunción de que donde está la cosa materia del litigio, las personas que intervienen en el mismo, juez y litigantes, han de contar con los medios más fáciles para decidir sobre la suerte o sobre lo que atañe a dicha cosa. Como la parte a quien se concede el beneficio puede renunciar a él, resulta que ésta regla es optativa.

Debe tenerse en consideración que el precepto que estudiamos so refiere tanto a los bienes muebles como inmuebles porque el fundamento es igual para una y otra clase de bienes.

En la segunda parte del inc. $2^{\circ}$ del Art. 45, se decide sobre los diversos casos que pueden presentarse: 1) Que se trate de varios inmuebles, que estén situados en distintas jurisdicciones; $y, 2)$ Que se trate de un solo inmueble, situado entre varias jurisdicciones En ambos casos la regla es la misma: es competente el juez del lugar donde se encuentra ubicado cualquiera de los inmuebles.

(1) Chiovenda.- Principio. - Pág. 35.- Alsina.- Tratado: T. C., pág. 205.

(2) Couture. - Fundamentos de D. P. - Pág. 31.

(3) Alsina, ob. ant., pág. 206. - T. I.

(4) Aisina, ob. ant., pág. 207. - Idem. 
4. Determinación de la competencia por el forum gestae administrationne.- Inc. $3^{\circ}$ del Art. 45. - Art. 45, segunda parte.

Según éstos preceptos es juez competente el del lugar donde se desempeña la administración en el momento de la demanda, en las acciones sobre rendición y aprobación de cuentas de bienes ajenos; y en los juicios de quiebra y suspensión de pagos, el del lugar donde el deudor tiene su principal establecimiento.

También su fundamento está, como en el caso del forum domicilio en la facilidad de que se siga la acción en el lugar donde deben encontrarse los documentos $y$ demás elementos comprobatorios de dichas cuentas.

49 Determinación de la competencia para los juicios de desahucio $Y$ retracto.- Inc. $4^{\circ}$ del Art. 45.- Esta clase de demandas deben interponerse ante "el juez del lugar en que se encuentra el bien.

Se trata de reglas especiales establecidas por la naturaleza de estas acciones. Como ya se ha dicho que las acciones reales son las que provienen no sólo de los derechos reales, sino de las pretensiones de este carácter - que se refieren a cosas, en forma muy extensiva, se podría aplicar a estos casos y comprenderse dentro del análisis que se ha hecho a la regla res sitae.

59 Determinación de la competencia por la cuantía.-La cuantía de termina la competencia y también el procedimiento a seguirse de tal manera que los mismos jueces deben tramitar según la ley procesal de distinta manera los asuntos que se le plantean, por razón de su cuantía.

Es indudable que el valor de la materia del litigio no afecta al interés de la justicia, para la cual el derecho en sí es respetable y digno de amparo prescindiendo de su monto.

Pero por razones de economía conviene que los gastos del procedimiento estén en proporción a la cuantía del litigio. Los gastos se reducen, reduciéndose el procedimiento. Atendiendo a éstas razones por razón de la cuantía se justifica que haya una competencia especial, la de los jueces ante quienes la tramitación de los procesos se hace en forma sumaria $Y$ en algunos casos gratuita.

Las reglas que consigna nuestro $C$. de P. C., para la determinación de la cuantía de los juicios están contenidos en los Arts. 296 al 305, reformados primero, por la Ley 11362 y después por la Ley 12036, de 25 de Noviémbre de 1958.

Según la legislación vigente, son juicios de mínima cuantía Ouzgado de Paz), aquellos cuyo monto no pasa de S/. 1,200.00; de menor cuantía si su valor pase de un mil doscientos soles $y$ no excede de $S / .10,000.00$; juicio ejecutivo desde $\mathbf{S} / .1,200.00$ y juicio ordinario el que excede de $\mathbf{S} /$. $10,000.00$.

Pero la determinación de este última vía está sujeta a estas reglas: Corresponde la vía ordinaria:

10- A aquellas acciones cuya cuantía, según lo dicho, no exceda de $\$$ S/ . 10,000:00. 
2 - $\bar{A}$ aquellas en que la cuestión sub-litis es inapreciable en dinero.

$3^{\circ}-\bar{A}$ las que no tienen tramitación especial señalada en el C. de P. C. Esta condición última prevalece sobre la cuantía. Así aunque un interdicto sobrepase la suma de S/. $10,000.00$ no se tramita por la vía ordinaria porque esta clase de acciones tienen una tramitación especial. Lo mismo los juicios de nulidad de matrimonio $y$ divorcio que aunque su materia es inapreciable en dinero no se tramitan tampoco como juicio ordinarios porque también tienen una tramitación particular y propia fijada en el Código Procesal.

Además el C. de P. C., vá señalando reglas especiales para los diversos casos que se resumen en las siguientes reglas:

1) Para la determinación de la cuantía sólo se tiene en cuenta los frutos, pensiones o intereses devengados y no los futuros, según el Art. 297 del C. de P. C.

Esto significa que el tiempo en que debe hacerse la valorización de las cosas, es el del momento de iniciarse la acción.

2) En las demandas sobre pensiones o rentas futuras (Ant. 298): "Si la demanda versa mejor derecho a alguna pensión o renta futura, por tiempo indeterminado, se fijará como valor del juicio el de las pensiones o rentas de diez años. Pero si el juicio versa sobre la validez o vigencia de la obligación, se calculará la cuantía por el valor del capital que, al seis por ciento al año, produzca la pensión o renta. Si el capital es redimible, se tomará como valor el de la redención según la ley". Se pueden distinguir así tres casos: A) si la acción versa sobre el mejor derecho a percibir la pensión o renta en cuyo caso la cuantía se determina por el importe de las pensioses o rentas de 10 años; B) si versa sobre la validez o vigencia de la obligación, se fija la cuantía del pleito en estas dos formas: - 1). Si el capital no es redimisible por el valor del capital que al $6 \%$ al año produzca la renta. Su monto determinará el juicio que corresponde. Hay que establecer una proporción aritmética (1) o emplear las fórmulas existentes. C) si el capital es redimible, censo, capellanía, enfiteusis, según las leyes sobre el particular (2), la cantidad que hay que abonar para la redención tija la cuantía.

3) En caso de varios demandados: "Si son varios los demandados, el valor total de la cosa o prestación según el Art. 299 determinará la: cuantía del pleito, aunque la obligación no sea solidaria".

El valor total de la cosa o prestación determinará la cuantía del pleito. aunque la obligación no sea solidaria. Es el caso de litis consorcio pasivo. Con tal que emanen de un mismo título pueden acumularse las acciones que uno o varios tienen contra varios $y$ en éste caso la suma total señalala cuantía del juicio.

4) En el caso de varias acciones acumuladas en la misma demanda establece la regla el Ant. 309: "Si una demanda, comprende varias: acciones, la cuantía se fijará por la suma del valor de todas".

(1) Romero. - Ob. cit. - T. 29. pág. 28.

(2) Leyes de Dic. 1829. 28 Oct. 1945, 4 Set. 1849 y 10 Oct. 1893. 
5) Caso de acción y reconvención -Art. 328-. "Para los efectos de la naturaleza del juicio, se considera el monto de lo reclamado por vía de reconvención, separadamente del valor que es materia de la demanda".

No se acumulan o suman el monto de lo demandado con el monto de lo reconvenido sino que para los efectos de la naturaleza del juicio (mayor o menor cuantía) ambos montos deben considerarse separadamente. Así demandado el pago de S/. 6,000.00 en la vía del juicio de menor cuantía, si se deduce una reconvención por igual suma; apesar de que el monto de ambos sobrepasa a la cantidad de S/. 10,000.00 que es el límite de la cuantía para esta clase de juicios, como no se suman, el procedimiento correspondiente es el de menor cuantíc.

Entonces pueden presentarse dos casos: 1) La reconvención, por sí, separadamente, es también, como la demanda de menor cuantía; ésto es que no sobrepasa la cantidad de S/. 10,000.00. En este supuesto, el juicio sigue como de menor cuantía.- 2) La acción es de menor cuantía, pero la reconvención es de mayor cuantía. Art. 25l, en cuyo caso el juicio seguirá como de mayor cuantía.

El precepto se funda en que en ningún caso una acción o reconvención de mayor cuantía puede ventilarse por los trámites más reducidos, de los juicios de menor cuantía, aunque la inversa si sea posible porque entonces no hay sino mayor amplitud para el planteamiento y debate de la cuestión propuesta lo que no perjudica la administración de justicia. En este segando caso en cuanto a la forma, la reconvención debe establecerse por escrito, contestándose a la vez la demanda.

En cuanto al momento de interponerla, debe hacerse en cualquier momento antes del comparendo de que trata el Art. 937, o en el acto de realizarse dicho comparendo, el que por lo mismo ya no se efectuará.

Obligación de fljar la cuantía. - Sólo existe expresamente establecida para el caso de demanda sobre cosa o prestación apreciable en dinero, Art. 302. Lo cual es claro, desde que la acción relativa a algo no apreciable en dinero, se sigue por la vía ordinaria. Sólo es necesario en los demás casos, establecer la vía que les corresponde en razón de la cuantía.

Es consecuencia de la determinación de la cuantía según el mismo precepto citado, la obligación del juez de tramitar la causa conforme a lo manifestado por el actor, sin admitir oposición, ni excepción -Art. 302-, salvo que meramente por lo expuesto en la demanda, sin recurrir a otra prueba, el juicio no tenga la cuantía que el actor le atribuye. Es pues simplemente el caso, de que haya en la demanda un error de cálculo.

Sólo en este caso puede el juez de oficio o a petición de parte, a mérito de reposición, dar a la causa la tramitación que le corresponde o inhibirse de su conocimiento si considera que su conocimiento corresponde a un Juez de Paz.

Es de notar que contra el auto del juez que resuelva no inhibirse o que la causa es de mayor cuantía, no se concede recurso alguno, conforme a la última parte del Art. 303. Esto es que cuando tramita como de menor cuantía una causa de mayor cuantía, entonces sí cabe anularse lo actuado 
a pedido de parte únicamente, según el Art. 304; lo que se fundamenta en las razones que ya se han expuesto.

En resumen, que por razón de la cuantía un juicio sólo puede anularse bajo estas condiciones: 1) que se haya seguido como juicio de monor cuantía el que debe ser de mayor cuantía, no a la inversa, 2) Quo se solicite la nulidad por las partes.

Podría esto hacer aparecer como que las partes pueden a su arbitrio discutir por los trómites del juicio de menor cuantía una cuestión que corresponde en rigor al de mayor cuantía, pues bastaría que una persona la promueva indebidamente en la primera vía y la otra parte no se oponga y que el juez tiene que asistir impasible e impotente a esta contravención de las leyes procesales sobre competencia $y$ tramitación y resuelto por la podría seguir por vía sumaria un juicio que debería ser tramitado y resuelto por la vía de mayor cuantía.

Esto no es lo que establece por supuesto la ley porque solo cabe que un juicio de menor cuantía se ventile por la vía de mayor cuantía.

Lo único que se deja a la voluntad de las partes es que se ventile por términos más extensos y latos de los que la ley establece, pero como la reducción de los mismos sólo se ha establecido en beneficio de las partes y no afecta a la administración de justicia, porque no hay omisión, sino exceso de tramitación, la regla está justificada.

La nulidad se tramita y resuelve junto con lo principal. Esto le hace revestir la calidad de una excepción perentoria que puede confundirse con la excepción de naturaleza de juicio o con la de incompetencia, según los casos.

Por lo mismo que debe tramitarse junto con la principal, no cabe conforme al texto de la ley, formar incidente en cuerda separada, apartándose de las reglas generales al respecto $y$ aún que haya muy autorizada opinión en contra de ésto.

Debe tenerse también en consideración que sólo se trata de reglas referentes a la cuantía, así que si un juicio no por su cuantía, sino por su propia naturaleza se debe ventilar como juicio de menor cuantía ya no se aplican las reglas que estudiamos.

Así un juicio de retracto que se tramita como de menor cuantía no podría ser convertido ni por voluntad de las partes, en juicio ordinario. Hay un interés particular, en que no se mantenga la inseguridad de la venta y una regla especial para el procedimiento en relación con este principio que no admite derogación por la voluntad de las partes. Así en los demás casos similares, en los que la tramitación se establece por la naturaleza de la accion y no por la simple cuantía del pleito.

Sanción por la exageración de la cuantía - Art. 305- "El demandante pagará las costas ocasionadas por la manifiesta exageración de la cuantía del pleito". 
Si bien el actor o el reconviniente pueden fijar voluntariamente la cuantía del pleito y conforme $\alpha$ ella debe tramitarse obligatoriamente la causa (art. 302) salvo que haya un error manifiesto y numérico (art. 303; en cuyo caso no hay voluntad, este poder tiene que ser sancionado cuando se abuse de él, para ocasionar perjuicios al otro litigante. La sanción está constituída por la condena en costas. El art. 305 establece que el demandante pagará las costas ocasionadas por la manifiesta exageración de la cuantía del pleito.

En general la condena en costas es una sanción para el litigante perdedor quien debe reintegrar al victorioso de los gastos que le ha ocasionado al litigar con indudable malicia. Pero en el caso que consideramos puede ser el propio victorioso el que debe pagar las costas.

Se debe relacionar este art. del C. de C. P. con el que señala que sólo el que ha perdido totalmente el juicio está obligado al pago de costas.

$\mathrm{Si}$ el actor aunque exageró la cuantía no perdió totalmente el juicio. la condena en costas sería improcedente, basta con perder las que pudo abonarle el demandado.

Quizá lo que se ha querido establecer es más bien una reparación de los daños y perjuicios que el abuso del derecho del actor significa la injustificada exageración de la cuantía que al optar por una vía más gravosa, ha ocasionado al contrario.

Pero en esta supuesta interpretación deben regir los principios generales sobre reparación de daños y perjuicios, sin referirse especialmente a las costas.

60-Determinación de la competencia para casos especiales.-El C. de P. C. consigna otras reglas en los arts. 47 y 50 , fijando como juez competente el del último domicilio del causante, para la declaración de herederos, optativo con el fuero rei sitce (art. 47) y del último domicilio conyugal para los juicios sobre divorcio y nulidad de matrimonio.

El art. 54 advierte que hay otras reglas especiales para la determinación de la competencia. Caso de la declaración de ausencia etc. en el C. C. y también en el C. de C.

Medios para hacer efectivas las reglas que determinan la competencia.-Nuestra ley franquea dos medios para dar eficacia a las normas sobre competencia: la excepción que llama impropiamente declinatoria de jurisdicción en vez de decir de competencia, y la contienda de competencia según el art. 56, que a la letra dice: "El que ha sido demandado ante un juez incompetente, puede ocurrir ante él declinando de jurisdicción o ante su juez propio para que promueva la contienda de competencia".

La primera se plantea por la persona indebidamente emplazada por un juez, ante este mismo juez que considera incompetente para que decline seguir interviniendo en la causa y asi constituye una acción declinatoria.

Esta excepción es por su naturaleza una excepción dilatoria, esto es, que debe interponerse antes de contestar la demanda devuelve pidiendo también al momento de absolver este trámite. Su estudio corresponde a la parte del C. de P. C. relativa a las excepciones. 
La segunda, es una acción inhibitoria porque por medio de ella la persona indebidamente demandada ante un juez al que cree no corresponderle el conocimiento de la causa, se presenta ante el juez que estima le corresponde para que se decida aún contra la voluntad del juez originario, que no le toca a éste el conocimiento de tal asunto.

Ámbos medios se excluyen, es ésto que el que emplea uno de los medios indicados no puede usar el otro simultánea ni sucesivamente (art. 57).

Esta contienda de competencias se funda en que los jueces tienen a la vez el derecho $y$ el deber de conocer de las cuestiones que la ley ha fijado como de su competencia. Esto es, que tienen el derecho de excluir $a$ otros jueces que indebidamente intervengan en estos juicios; $y$ la obligación de no intervenir en los asuntos que estime no son de su competencia. Así el juez que a pedido de parte ve usurpada o tomada su propia competencia por otro juez, debe instaurarle una contienda para que se establezca a quien le toca el conocimiento de la cuestión. Esto constituye la contienda de competencia positiva.

Otras veces cuando los jueces estiman que ellos no tienen sino otros jueces, la competencia para el caso propuesto, deben pasarle el asunto al juez que estimen competente, y si éste se negara a recibirlo por considerarlo también fuera de su competencia, se produce la contienda de competencia negativa.

Así ambas formas de contienda tienen el mismo objetivo, esto es, que se regularice el procedimiento pasando su conocimiento del juez incompetente al juez competente.

Contienda de competencia positiva.-Consiste en el recurso del que habiendo sido demandado ante un juez incompetente recurre ante su juez propio, a fin de que promueva contienda (art. 56). para que se establezca a quien le corresponde el conocimiento del caso.

Tramitación.-Está establecida en los arts. 56 a 57 del C. de P. C. distinguiéndose estas etapas.

1) Se interpone por el demandado ante su propio juez. A este respecto debe hacerse notar que la contienda no se promueve sino por gestión de parte y en ningún caso, de oficio, según lo establece el art. 66 del C. de P. C. La razón es clara, puede admitirse la prórroga de la competencia según las reglas ya estudiadas.

En el supuesto de que el juez crea que no le corresponde el conocimiento del asunto, lo pasa al juez que considera competente. Sus consecuencias se expondrón al tratar de la contienda negativa de competencia.

Se interpone pues, por el demandado, ante su juez propio, entendiéndose por éste el juez a quien estima corresponde el conocimiento del caso; en lo que se diferencia de la excepción declinatoria de competencia.

2) El término para interponerla es de seis días contados de la primera notificación, salvo el término de la distancia. Deben aplicarse para su cómputo las reglas relativas a los términos procesales. Este es un término perentorio según el art. 58. 
3) El juez, ante quien se ocurre, mandará que el interesado pruebe dentro de tercero día, que le corresponde el fuero que solicita, conforme al art. 59.

Se puede hacer uso para esto de cualquiera de los medios probatorios permitidos por la ley. Precisamente por ésto sin duda es que se ha considerado el indicado plazo insuficiente (1) para actuar por lo menos ciertas probanzas, como la testimonial.

Pero debe también considerarse que generalmente se trata de fáciles comprobaciones porque o se alega el hecho del domicilio en un lugar determinado o la existencia de un contrato por el que se ha convenido un fuero distinto. Desde que la competencia exclusivamente se decide por el convenio o por el domicilio del demandado la prueba sólo se referirá a uno u otro hecho.

4) Vencido el término probatorio hállase o no producido prueba (art. 60): "El juez oficiará con noticia del interesado, al juez que empezó a conocer remitiéndole copia de lo actuado". El juez: a) oficia al juez que empezó a conocer, esto es, al juez que ha citado al demandado, haciéndole conocer la existencia de la contienda promovida. Hasta este momento dicho juez ni el actor tienen conocimiento de ella. Sin embargo el art. 65, fijando los efectos del recurso que nos ocupa, establece que: "durante la sustanciación de la competencia, uno y otro juez se abstendrán de todo procedimiento sobre lo principal, salvo que se trate de practicar alguna diligencia cuya omisión causaría a la parte que la solicita un perjuicio irreparable".

Para subsanar esta incongruencia de la ley, la práctica ha establecido que el demandado al solicitar que se promueva la contienda pida que se oficie al juez que lo ha emplazado, haciéndole conocer el recurso que está haciendo valer. En el Anteproyecto de C. de P. C., se salva la dificultad, ordenándose que el juez de oficio, al presentarse la contienda, lo haga saber al juez de la causa.

b) Con citación del interesado, debe el juez pasar dicho oficio, ésto es avisándole para que haga valer los derechos que le corresponden en el incidente de competencia. Esto significa que la contienda no sólo es cuestión entre jueces, sino que los interesados son parte en el incidente.

c) Remitiéndole copia de lo actuado. De tal manera que el expediente original de la contienda queda en su poder. Esto trae también las conse. cuencias de la dilación y el gasto consiguiente a la expedición de las copias. En el mencionado Anteproyecto de reforma procesal, se modifica esta situación ordenándose la remisión del expediente original no habiendo ninguna razón para que se conserve en el Juzgado donde se promovió la competencia.

Con esto termina la intervención del juez propio del demandado y pasa la tramitación de la contienda al juez que ha citado con la demanda y ante él va ha seguirse un procedimiento análogo al que se ha efectuado ante el juez anteriormente indicado.

5) El juez al recibir el oficio, corre traslado al demandante (Art. 61).

(1) J. G. Romero. - Ob cit., pág. 91. T. I. 
El demandante tiene las posibilidades de: a) allanarse a la inhibición, en cuyo caso el juez la decretará y remitirá todo lo actuado al otro juez, con citación de parte, quedando en esta forma, terminado el incidente; b) de contradecir la inhibición. Según el Art. 62: "Si el demandante contradice la inhibición, el juez mandará que pruebe dentro de tercero día los hechos en que funda la contradicción $y$ vencido el término, elevará todo lo actuado, inclusive lo relativo a lo principal, con citación de parte, al tribunal que debe dirimir la competencia. Al mismo tiempo dirigirá oficio al otro juez. dándole aviso de la remisión de los antecedentes a ese Tribunal; $\mathrm{y}$, el contenido de éste oficio se mandará poner por el juez que lo recibe en conocimiento de la parte que solicitó la competencia". Así que en éste caso de contradicción continúa la tramitación de la contienda de competencia así:

6) El juez mandará que pruebe dentro del tercero día los hechos en que funda la contradicción (Art. 62). Nade valen las alegaciones de los litigantes mientras que no están comprobadas.

7) El juez eleva todo lo actuado, inclusive lo principal, con citación de parte, al Tribunal que debe dirimir la competencia.

8) Al mismo tiempo dirigirá oficio al otro juez, dớndole aviso de la remisión de los antecedentes al Tribunal. Juzgado.

Con este trámite termina la sustanciación de la contienda ante este

9) El juez que promovió la contienda al recibir el oficio comunicándole la remisión de lo actuado al Tribunal, lo pone en. conocimiento de la parte que solicitó la competencia, también con el objeto de que conozca el estado de la causa y se ponga a derecho. Así resulta que cada parte conoce las actuaciones de la contienda hasta ahora, por intermedio de sus propios jueces.

10) La contienda pasa al Tribunal que debe dirimirla.-El Tribunal al que debe remitirse la contienda para su resolución depende:

a) Si se trata de competencia entre jueces de un mismo distrito judicial y entre jueces de Primera Instancia comunes o privativos, es la Corte Superior del Distrito Judicial al que pertenecen todos los jueces, según el Art. 67.

Se entiende por Distrito Judicial, la circunscripción territorial dentro de la cual los jueces en conflicto ejercen jurisdicción.

b) Sì se trata de jueces de distinto Distrito Judicial, es la Corte Suprema. El Art. 66 a que se refiere el Art. 67 del C. de P. C., es de la Constitución del 60, que establecía que en caso de conflicto entre la Corte Superior y Suprema, dirimía la competencia el Senado, pero no ha sido mantenida o en la Constitución vigente. Esto ademós hubiera sido inútil según el Art. 68 del C. de P. C. Por éste Art. 68, sólo la Corte Suprema puede arocarse el conocimiento de las causas que le corresponden entender originariamente y de que está conociendo otro juez o Tribunal. Así resulta juez de su propia causa, lo que se justifica por no haber otro Tribunal de mayor jerarquía.

i1) El Tribunal dirimente resolverá la competencia por el sólo mérito de los autos (Art. 63). Esto es sin que pueda solicitar alguna otra compro- 
bación. La Corte Suprema resuelve sin el dictamen fiscal previo, que se exige en los demás casos.

12) Contra la resolución que resuelve la competencia hoy recurso de nulidad, siempre por supuesto, que el dirimente no sea la propia Corte Suprema (Art. 63).

13) Ejecutoriada o consentida la resolución del dirimente, éste remite los autos al juez deciarando competente y da aviso al otro juez.

Estado del juicio durante la sustantación de la competencia, Art. 6."Durante la sustanciación de la competencia, uno y otro juez es abstendrán de todo procedimiento sobre lo principal; pero si es urgente practicar alguna diligencia cuya omisión causaría $\alpha$ la parte que la solicita un perjuicio irreparable, la ordenará cualquiera de los dos, haciendo constar la urgencia".

La contienda de competencia constituye una cuestión perjudicial (1) que exige por lo tanto ser resuelta antes de entrarse al fondo del pleito. En caso contrario se estaría permitiendo la intervención de un juez incompetente o de uno cuya competencia no está establecida. Por esto es que durante la tramitación de la competencia, uno y otro juez deben abstenerse de todo procedimiento sobre lo principal. Pero la regla admite excepciones. Según la segunda parte del citado precepto legal cualquiera de los dos jueces puede practicar las diligencias con estas condiciones: 1) que sean urgentes; 2) que su omisión cause a la parte que la solicita perjuicio irreparable; $y, 3)$ con constancia de la urgencia.

Sin duda que entre estas condiciones faltaría una cuarta que puede prevenir la posibilidad de resoluciones contradictorias, cual es la de avisar al otro juez la medida decretada.

Contisnda de competencia negativa.-Se produce en el caso de que el juez ante quien se presenta la demanda se inhiba o excuse de su conocimiento y lo pase $\alpha$ otro juez, que estima competente y éste $\alpha$ su vez, considerando infundado la excusa, la devuelva al originario. Así pues ocurre cuando ninqún juez se considera competente.

Su tramitación está fijada en el Art. 69: "El juez a quien se pase una causa por excusa de otro que se cree incompetente o impedido, puede, si la considera infundada, devolver los autos inmediatamente exponiendo sus razones. En caso de insistir en su excusa el primer juez, remitirá el expediente, en el mismo día al Tribunal a quien correspondería dirimir la competencia conforme al Art. 67. Así los trámites son los siguientes:

1).-El juez a quien se remiten los autos por excusa de otro, los devuelve a éste último inmediatamente, exponiendo sus razones. La excusa debe ser fundamentada pues constituye un deber de los jueces aceptar y conocer de los asuntos que se le plantean dentro de los límites de su competencia.

2).-El juez originario puede: $\alpha$ ) no insistir en su excusa, en cuyo caso queda terminado el incidente y fijada su competencia; b) insistir en su inhibición en cuyo caso deberá remitir el expediente en el mismo día, al Tribunal a quien corresponde dirimir la competencia conforme al Art. 67.

(1) Do la Plaza. - Ob. cit., pág. 334 . 
Conflicto entre jueces $y$ autoridades administrativas. - Dentro del capítulo que trata de la competencia, el legislador fija las normas a que debe sujetarse la resolución de los diversos conflictos que se pueden presentar entre el Poder Judicial y el Poder Administrativo o sea el Poder Ejecutivo.

El punto tiene dificultades desde que ambos poderes, teóricamente, son iguales y porque hay que dar la facultad de resolver la competencia a una de las partes interesadas (1).

La dificultad se ha resuelto estableciendo una jerarquía entre: a) jueces de Paz y autoridades distritales; b) jueces de Primera Instancia y autoridades provinciales; c) entre Corte Superiores y autoridades departamentales, correspondiendo dirimir la competencia a la autoridad judicial del grado inmediato superior a los que se encuentran en conflicto.

\section{Tramitación.- Se sustancian en esta forma:}

1).-Se plantea la contienda ante el juez o Tribunal a quien corres. ponde resolver el conflicto (Art. 73).

Estos son a) los jueces de Primera Instancia si se trata de un conflicto entre jueces de Páz y los gobernadores, los tenientes gobernadores o Concejos Distritales; b) las Cortes Superiores si es el conflicto entre jueces de Prime Instancia y delegados departamentales $\mathrm{y}$ otras autoridades provinciales por el Art. 70; c) la Corte Suprema si se trata de conflictos entre jueces y autoridades de Provincia que no corresponden a un mismo Distrito Judicial; - entre Cortes Superiores y prefectos $u$ otras autoridades departamentales.

Pueden plantearla: la parte interesada y el Ministerio Fiscal.

2).-Se tramita solicitándose informe a las autoridades entre las que existe el conflicto. No señala la ley, término para evacuar este informe. Habría por lo tanto que aplicar las leyes para casos análogos, esto es señalar el de tres días (Art. 59), o suponer que es un plazo cuya duración se ha dejado a la determinación judicial.

3).-Se requiere a las autoridades en conflicto para que expida el informe. La ley no dice bajo qué apercibimiento, pero como el requerimiento es siempre bajo la amenaza de una sanción, y relacionando los preceptos al respecto, se entiende bajo el apercibimiento de resolver sin oirla.

4).-Parece que se expide resolución sin que se pueda solicitar pruebas, por el simple mérito de lo actuado. Sin embargo, las pruebas que se pueden decretar de oficio no habría ninguna prohibición para omitirlas.

5).-De la resolución que se expida hay los siguientes recursos: a) el de apelación en doble efecto, si se trata de resolución expedida por Juez de Primera Instancia (Art. 70); b) recurso de nulidad, si la resolución la ha expedido la Corte Superior (Art. 71).

(1) De la Plaza. - Ob. cit.- Pág. 334. 